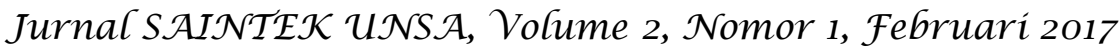

\title{
PERENCANAAN RUMAH PANGGUNG SUMBAWA DENGAN KONSTRUKSI KAYU
}

\author{
BADARUDDIN ${ }^{1}$, ADINOLLAH $^{2}$ \\ Dosen Program Studi Teknik Sipil Fakultas Teknik Universitas Samawa Sumbawa Besar ${ }^{1}$ \\ Mahasiswa Program Studi Teknik Sipil Fakultas Teknik Universitas Samawa Sumbawa Besar ${ }^{2}$
}

ABSTRAK

Indonesia memiliki keberagaman suku bangsa yang tersebar dari Sabang hingga Merauke. Tak heran setiap daerah memilik jenis rumah adat yang berbeda pula. Seperti halnya di pulau Sumbawa yang mayoritas penduduknya masih menggunakan material kayu sebagai bahan konstruksi rumah panggung.

Rumah panggung kayu adalah bangunan rumah dengan menggunakan sistem struktur rangka pemikul dari bahan kayu. Biasa disebut sebagai rumah kayu, ciri-cirinya yaitu seluruh komponen struktur atap, balok dan kolom serta dinding yang digunakan adalah kayu.

Perencanaan konstruksi rumah panggung diperhitungkan penggunaan kayu yang sesuai dengan kebutuhan beban yang bekerja seperti beban hidup, beban mati, dan beban angin yang terlihat pada dimensi kuda - kuda, balok dan kolom yang merupakan hasil perhitungan beban yang bekerja pada kontruksi atap. Dengan luasan rumah panggung $8 \times 11$ meter, jarak antar kuda - kuda 3 meter, serta jenis kayu yang digunakan adalah kayu jati dengan klasifikasi kuat kayu kelas II, perhitungan dilakukan dari konstruksi atap dengan sudut kemiringan atap $30^{\circ}$ dan penutup atap genteng dengan melakukan analisis rangka batang menggunakan cara analitis dengan metode keseimbangan titik buhul dan cara grafis dengan menggunakan metode cremona.

Berdasarkan hasil analisis tersebut didapat dimensi gording dengan ukuran $8 / 10 \mathrm{~cm}$, balok tarik $6 / 12 \mathrm{~cm}$, kaki kuda - kuda 6/12 cm, sekur 6/12. tiang kuda - kuda $6 / 12 \mathrm{~cm}$, balok lantai $8 / 12 \mathrm{~cm}$, dan kolom 16/16 cm, sehingga dengan demikian perencanaan rumah panggung dapat diminimalisir penggunaan material kayu yang efisien.

Kata kunci: Rumah Panggung Sumbawa, Konstruksi Kayu.

\section{PENDAHULUAN}

Indonesia memiliki keberagaman suku bangsa yang tersebar dari Sabang hingga Merauke. Setiap daerah memilik jenis rumah adat yang berbeda pula. Seperti halnya di pulau Sumbawa yang mayoritas penduduknya masih menggunakan material kayu sebagai bahan tempat tinggal. Rumah konstruksi kayu adalah bangunan rumah dengan menggunakan sistem struktur rangka pemikul dari bahan kayu, biasa disebut sebagai rumah kayu, ciricirinya yaitu seluruh komponen struktur atap, balok dan kolom serta dinding yang digunakan adalah kayu.

Rumah Panggung Kayu merupakan salah satu rumah tradisional Sumbawa yang berbentuk persegi empat memanjang ke belakang. Konstruksi bangunan rumah ini dibuat secara lepas-pasang (knock down) sehingga dapat dipindahkan dari satu tempat ke tempat lain.
Konsep empat persegi panjang ini bermula dari pandangan hidup masyarakat Sumbawa pada zaman dahulu tentang bagaimana memahami alam semesta secara universal. Menurut cerita, pada awalnya rumah panggung tersebut dibangun karena masyarakat setempat umumnya hidup dan bertempat tinggal di sekitar pantai. Sehingga untuk menghindari gelombang air laut, dibutuhkan rumah tempat tinggal yang lantai dasarnya tidak langsung menempel ke tanah.

Berdasarkan beberapa pendapat orang sumbawa tentang konstruksi rumah panggung kayu bahwa zaman dahulu orang Sumbawa membangun kontruksi kayu hanya berdasarkan logika tanpa memikirkan tingkat keamanan dan tingkat ekonomis dari penggunanaan kayu tersebut, sehingga terlihat boros dalam penggunaan kayu, sehingga dalam penelitian ini akan memaparkan mengenai tata cara 
perencanaan konstruksi rumah panggung Sumbawa yang benar dan aman.

Konsep rumah panggung memiliki skenario antisipasi dan pencegahan. Secara sederhana konsep rumah panggung merupakan bangunan berkaki dimana dasar bangunan diangkat keatas sehingga tidak menyentuh tanah. Jarak lantai bangunan dari tanah variatif, antara satu sampai dua meter. Jika dahulu rumah panggung dikonsep oleh orang - orang terdahulu agar hunian mereka terhindar dari binatang liar, sekarang rumah panggung bisa dikonsep sebagai alternatif untuk meminimalkan dampak akibat banjir dan gempa.

\section{METODOLOGI PENELITIAN}

Analisis struktur

Rangka atap

Atap adalah bagian yang penutup bangunan yang berfungsi sebagai pelidung bangunan dari panas dan hujan.

Ada beberapa syarat yang harus dipenuhi untuk pekerjaan atap adalah :

a) Harus serasi dengan bentuk bangunannya sehingga dapat menambah keindahan bangunan.

b) Dibuat dengan kemiringan sedemikian, sehingga air hujan dapat cepat meninggalkan atap bangunan

c) Harus dibuat dari bahan yang tahan dan tidak mudah rusak oleh pengaruh cuaca, panas, hujan.

d) Dapat memberikan kenyamanan bertempat tinggal bagi penghuninya. Cara analitis

Cara analitis atau umumnya disebut sebagai metode keseimbangan titik buhul berprinsip pada keseimbangan suatu konstruksi, dimana pada sebuah konstruksi yang seimbang bila diambil pada sembarang bagian, maka bagian sebelah dari konstruksi akan melakukan keseimbangan gaya-gaya yang ada.

Prinsip pengerjaan dengan cara analitis ini adalah :

a) Terlebih dahulu hitung reaksi-reaksi pada tumpuan. b) Setiap simpul yang dibuat hendaknya jangan lebih dari tiga gaya batang yang tidak diketahui, untuk mempermudah dalam menentukan batang tarik dan batang tekan.

c) Setiap simpul dipisahkan satu sama yang lainnya.

d) Setiap titik simpul harus dalam keadaan seimbang akibat gaya luar yang bekerja pada simpul dan gaya dalam (gaya batang) yan timbul pada titik simpul yang di tinjau.

e) Untuk menghitung gaya - gaya dalam yang belum diketahui digunakan dalil: $\Sigma \mathrm{H}=0, \Sigma \mathrm{V}=0$, atau $\Sigma K x=0, \Sigma K y=0$.

f) Dimulai dengan meninjau titik simpul yang gaya batangnya 1 atau 2 batang yang belum diketahui.

g) Misalkan gaya yang arahnya keatas dan kekanan dianggap positif dan sebaliknya gaya yang arahnya kebawah dan kekiri dianggap negative.

h) Gaya batang yang arahnya meninggalkan titik simpul adalah batang tarik dan yang menuju titik simpul adalah batang tekan.

Cara Grafis

Metode cremona adalah metode penyelesaian gaya-gaya batang dengan cara grafis. Dalam metode ini yang perlu kita kuasai ialah pemahaman konsep perhitungannya.

Prinsip pengerjaan dengan metode Cremona ini adalah :

a) Hitung terlebih dahulu reaksi-reaksi tumpuan.

b) Tentukan skala gaya dan skala gambar untuk mempermudah perhitungan.

c) Namai tiap batang dan tiap titik buhul agar mudah dikenali dalam perhitungan nantinya.

d) Susunlah semua gaya - gaya luar yang dimulai dari kiri ke kanan atau sebaliknya dari kanan kekiri, mengelilingi konstruksi dan berilah anak panah yang menyatakan arah gaya dan dengan skala tertentu. 
e) Penijauan dimulai dari simpul yang mempunyai maksimum 2 buah gaya batang yang belum diketahui.

f) Lukiskan garis sejajar terhadap batang - batang yang ditinjau dan susunanya sesuai dengan arah susunan gaya - gaya luar.

g) Panjang garis - garis yang didapat menyatakan besar gaya batang menurut skala gaya yang diambil.

h) Bila gaya yang menuju titik simpul adalah gaya tekan (-) dan bila gaya meninggalkan titik simpul adalah gaya tarik (+).

i) Terakhir buatkan dalam tabel besarnya gaya tiap batang agar kita bisa menarik kesimpulan dalam perhitungan tersebut.

Metodologi perencanaan

Suatu perencanaan harus dilakukan dengan sistematika yang jelas dan teratur sehingga hasilnya dapat dipertanggung jawabkan. Dalam penelitian ini ada beberapa tahap yang harus dilakukan sebagai berikut :

a) Tahap I

Tahap persiapan. Persiapan dilakukan untuk mencari data, informasi, dan literatur untuk mendukung perencanaan struktur rumah panggung tersebut.

b) Tahap II

Pemodelan geometri struktur yang meliputi, denah rumah panggung, tampak dan potongan struktur.

c) Tahap III

Perencanaan atap yang meliputi perencanaan gording, struktur kudakuda dan menghitung gaya batang berdasarkan point ( 3.1 .2 dan 3.1.3) yang akan digunakan untuk perhitungan dimensi batang pada struktur atap rumah panggung.

d) Tahap IV

Perencanaan dimensi batang yang meliputi batang tekan dan batang tarik pada struktur atap rumah panggung.

e) Tahap V

Menghitung pembebanan dinding dan lantai yang bekerja terhadap balok dan kolom struktur rumah panggung.

f) Tahap VI

Pemilihan profil kayu untuk elemen utama struktur ( balok dan kolom).

g) Tahap VII

Tahap pengambilan kesimpulan. Pada tahap ini, dengan berdasarkan hasil analisis data dan pembahasan, dibuat suatu kesimpulan yang sesuai dengan tujuan penelitian.

\section{Bagan alir penelitian}

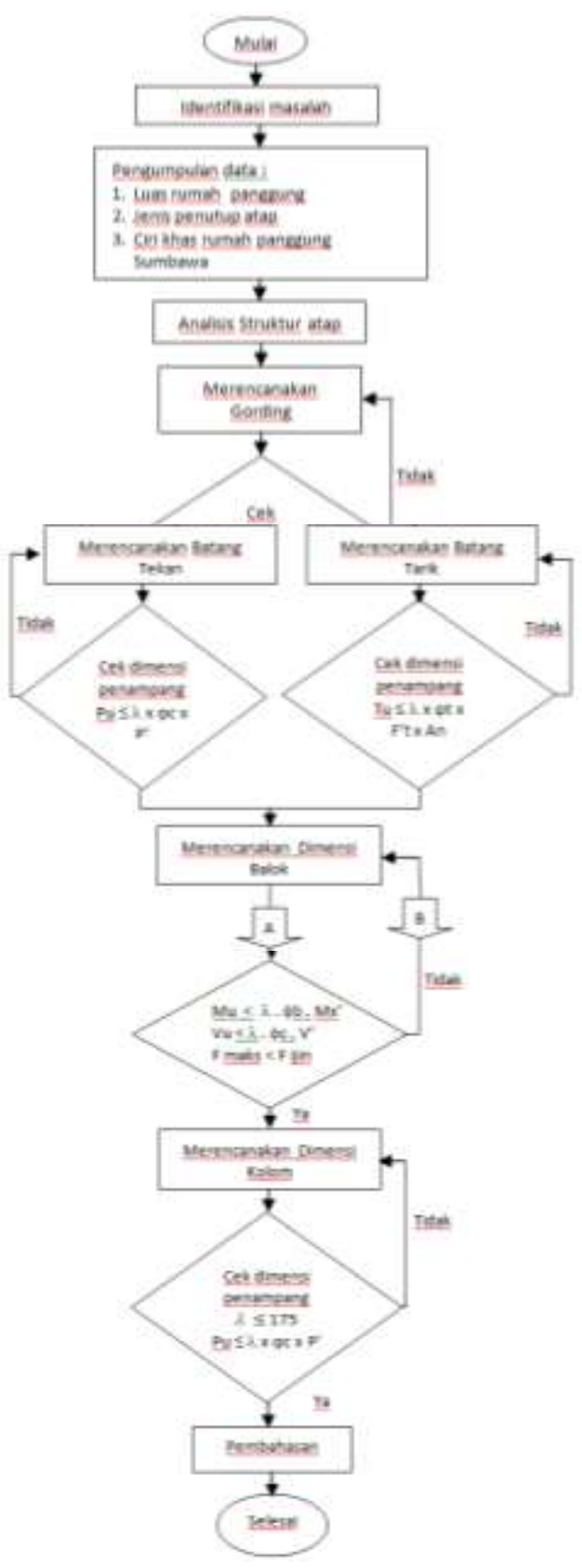




\section{ANALISA PERENCANAAN STRUKTUR}

Data umum

Adapun data awal yang digunakan dalam perencanaan konstruksi rumah panggung adalah sebagai berikut :

Luas rumah panggung

Rumah panggung Sumbawa memiliki luasan yang berbeda-beda namun seragam, dapat terlihat dari luas, ukuran kolom atau balok struktur dan konstruksi atap. Adapun luasan/denah yang akan direncanakan adalah sebagai berikut:

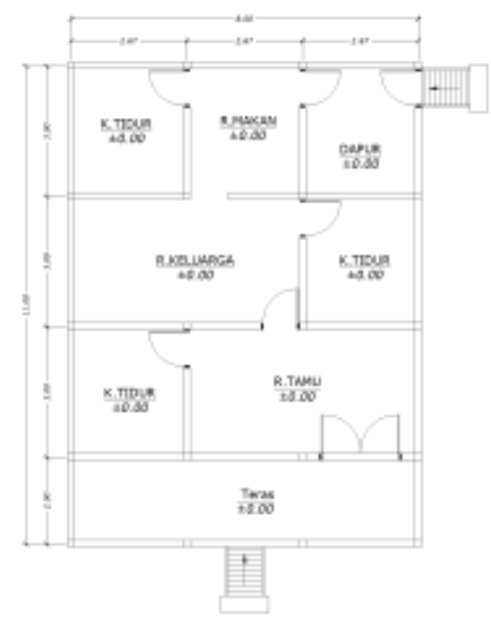

Gambar 1. Denah rumah panggung

Tampak rumah panggung

Pada umum nya model rumah panggung Sumbawa memiliki typical yang seragam. Adapun gambar tampak dari rumah panggung Sumbawa adalah sebagai berikut :

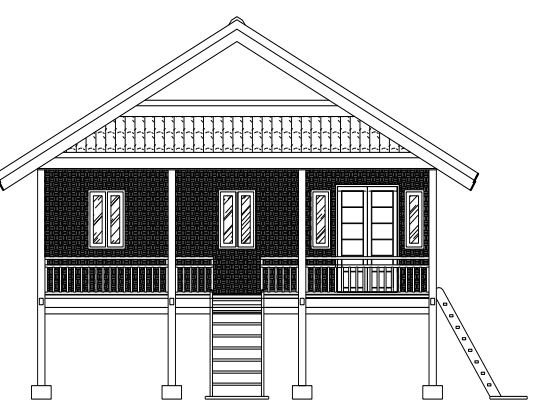

Gambar 2. Tampak depan

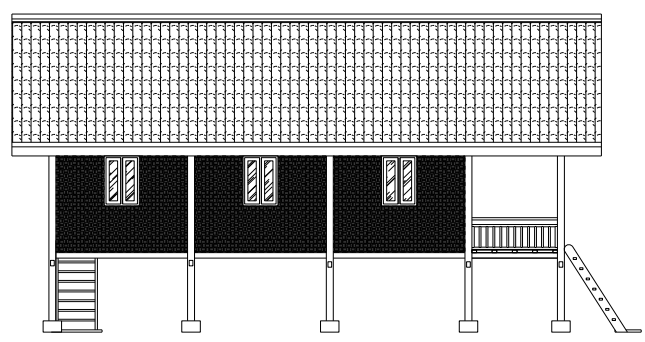

Gambar 3. Tampak samping kiri

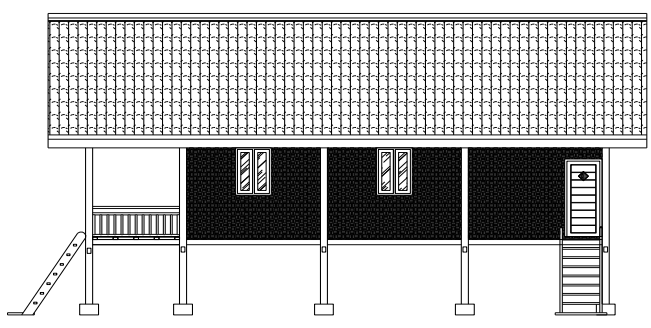

Gambar 4. Tampak samping kanan

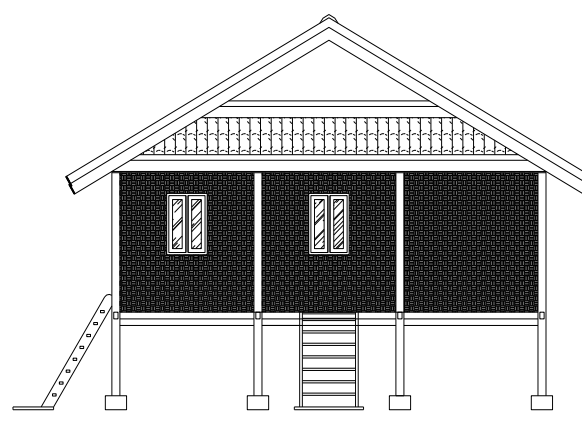

Gambar 5. Tampak belakang

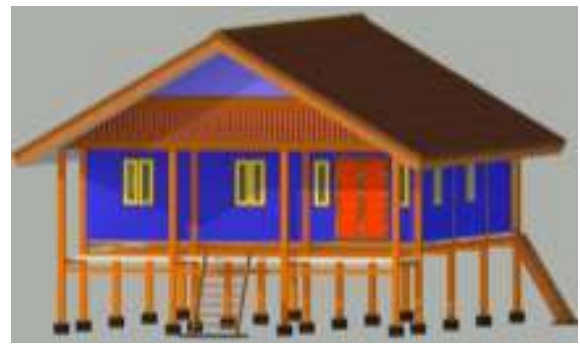

Gambar 6. Tampak visual (3D)

Potongan melintang struktur

Potongan melintang pada bangunan struktur adalah potongan yang ditinjau sebagai objek analisis sehingga mempermudah dalam perhitungan dari struktur tersebut. 


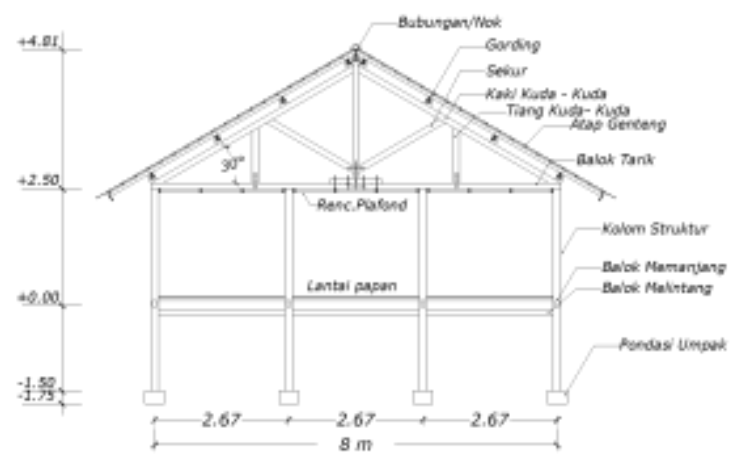

Gambar 7. Potongan melintang

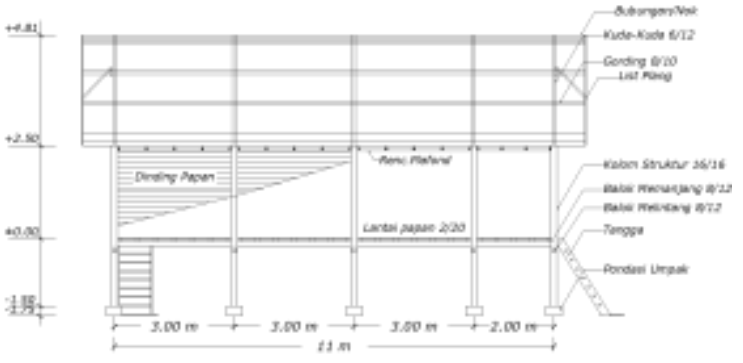

Gambar 8. Potongan memanjang

Perencanaan atap

Dalam perencanaan konstruksi kap atap digunakan konstruksi kayu dengan bentuk atap plana.

Adapun data perencanaa atap rumah panggung sebagai berikut :

a. Bentang kuda - kuda $=8$ meter

b. Jarak antar kuda - kuda $=3$ meter

c. Penutup atap (Genteng) $=50 \mathrm{~kg} / \mathrm{m} 2=$ $500 \mathrm{~N} / \mathrm{m}^{2}$ (PPURG 1987)

d. Kayu jati Sumbawa (Berat jenis) $=700$ $\mathrm{kg} / \mathrm{m}^{3}=7000 \mathrm{~N} / \mathrm{m}^{3}$ setara dengan kelas Kuat kayu Kelas II

e. Tiupan angin pada atap $(q w)=40 \mathrm{~kg} / \mathrm{m}^{2}$ $=400 \mathrm{~N} / \mathrm{m}^{2}$

f. Sudut kemiringan atap $=30$ derajat

g. Tritisan =0,8 meter Menghitung panjang batang

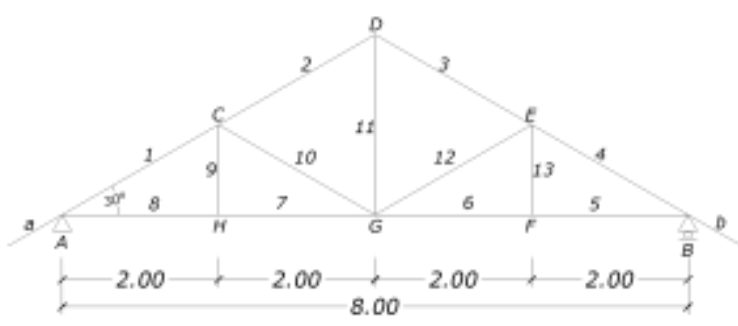

Gambar 9. Rangka kuda - kuda a. Panjang batang $1,2,3,4$ ( $A C D$ dan DEB)

$$
=\frac{2}{\cos }=\frac{2}{0.866}=2,31 \mathrm{~m}
$$

b. Panjang batang $5,6,7,8$ ( AHG dan GFB ) $=2 \mathrm{~m}$

c. Panjang batang 9,13 (HC \& HF) $=2 x$ $\operatorname{tgn} \alpha=2 \times 0.577=1,15 \mathrm{~m}$

d. Panjang batang 10,12 ( CG \& GE)

$$
=\frac{2}{\cos }=\frac{2}{0.866}=2,31 \mathrm{~m}
$$

e. Panjang batang $11(\mathrm{GD})=4 \times \operatorname{tgn} \alpha$ $=4 \times 0.577=2,31 \mathrm{~m}$

Tabel 1. Daftar panjang batang

\begin{tabular}{||c|c||}
\hline $\begin{array}{r}\text { Nama } \\
\text { batang }\end{array}$ & $\begin{array}{c}\text { Panjang } \\
\text { batang } \\
(\mathrm{m})\end{array}$ \\
\hline \hline 1 & 2,31 \\
2 & 2,31 \\
3 & 2,31 \\
4 & 2,31 \\
5 & 2,00 \\
6 & 2,00 \\
7 & 2,00 \\
8 & 2,00 \\
9 & 1,15 \\
1 & 2,31 \\
0 & \\
1 & 2,31 \\
1 & \\
1 & 2,31 \\
2 & 1,15 \\
1 & 0,80 \\
3 & 0,80 \\
$\mathrm{a}$ & \\
$\mathrm{b}$ & \\
\hline
\end{tabular}

Perencanaan gording

Gording merupakan balok atap yang berfungsi sebagai pengikat dan penghubung antar kuda-kuda. Gording juga menjadi dudukan untuk kasau. Didalam konstruksi kuda-kuda gording tergolong ke dalam jenis beban mati (dead load).

Menetapkan mutu kayu berdasarkan persamaan (2.2) $\mathrm{Ew}=16000 \mathrm{G}^{0,71}$ 


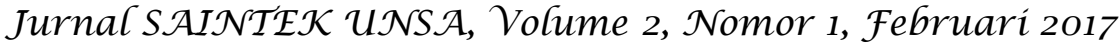

$$
=16000 \times 0,70^{0,71}=12421 \mathrm{Mpa}
$$

Dimana :

Ew = Elastisitas lentur terkoreksi (Mpa) $\mathrm{G}=$ Berat jenis kayu

Berdasarkan hasil diatas bahwa mutu kayu jati Sumbawa dapat digolongkan ke dalam kode mutu E14 dengan nilai $\mathrm{EW}=13000 \mathrm{Mpa}(\mathrm{SNI} 03-\mathrm{xxx}-2000)$. Jarak gording

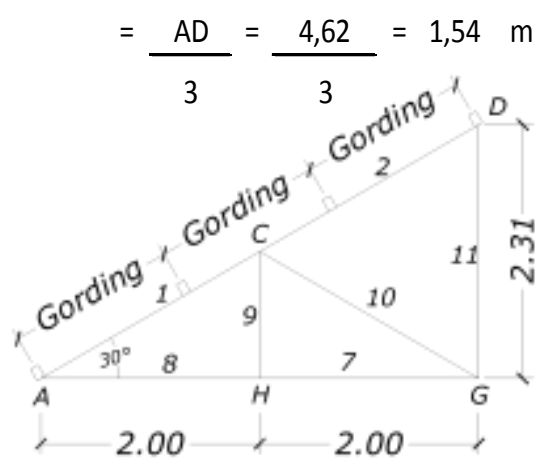

Gambar 10. Rencana

Gording

Adapun beban - beban yang bekerja pada atap :

a. Beban mati gording

Dicoba menggunakan kelas kuat kayu kelas II dengan ukuran $8 / 10 \mathrm{~cm}$ dengan berat jenis $=700 \mathrm{~kg} / \mathrm{m}^{3}=$ $7000 \mathrm{~N}^{3} \quad$ (Dinas Kehutanan Kab.Sumbawa)

Berat sendiri $=0,08 \times 0,10 \times 7000$

$=56,00 \mathrm{~N} / \mathrm{m}$

Berat atap ( genteng + reng + usuk )

$=500 \mathrm{~N} / \mathrm{m}^{2}$ (PPURG 1987)

$=500 \mathrm{xjarak}$ gording

$=500 \times 1,54$

$=769,800 \mathrm{~N} / \mathrm{m}$

$\mathrm{qd}=56,00+769,800$

$\mathrm{qd}=825,800 \mathrm{~N} / \mathrm{m}$

dimana :

$q d=$ beban mati gording $(\mathrm{N} / \mathrm{m})$

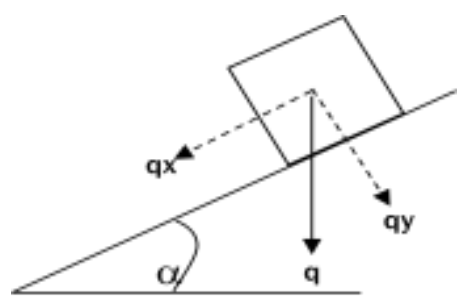

Gambar 11. Beban kerja gording

$$
\begin{aligned}
q x & =q d \times \sin \alpha \\
& =825,800 \times \sin 30 \\
& =825,800 \times 0,5 \\
& =412,900 \mathrm{~N} / \mathrm{m} \\
q y & =q d \times \cos \alpha \\
& =825,800 \times \cos 30 \\
& =825,800 \times 0,866 \\
& =715,164 \mathrm{~N} / \mathrm{m}
\end{aligned}
$$

b. Perhitungan momen akibat beban mati gording.

Adapun gaya momen yamg bekerja pada gording adalah :

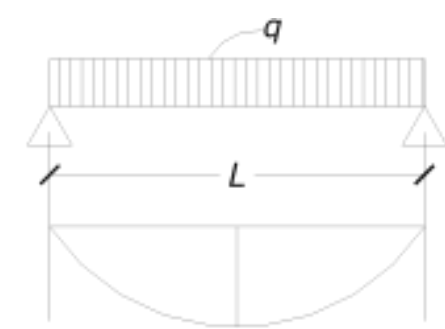

Gambar 12. Momen lentur akibat beban mati

$$
\begin{aligned}
M \times 1 & =1 / 8 \times q \times \times L^{2} \\
& =1 / 8 \times 412,900 \times 3^{2} \\
& =464,513 \mathrm{Nm}
\end{aligned}
$$

My1 $=1 / 8 \times q y \times \mathrm{L}^{2}$

$$
\begin{aligned}
& =1 / 8 \times 715,164 \times 3^{2} \\
& =804,560 \mathrm{Nm}
\end{aligned}
$$

dimana :

$$
\mathrm{L}=\text { Jarak antar kuda - kuda }(\mathrm{m})
$$

c. Beban hidup pada gording Untuk beban pada kuda - kuda diperhitungka suatu beban terpusan $\mathrm{P}=100 \mathrm{~kg}=1000 \mathrm{~N}$ (PPURG 1987)

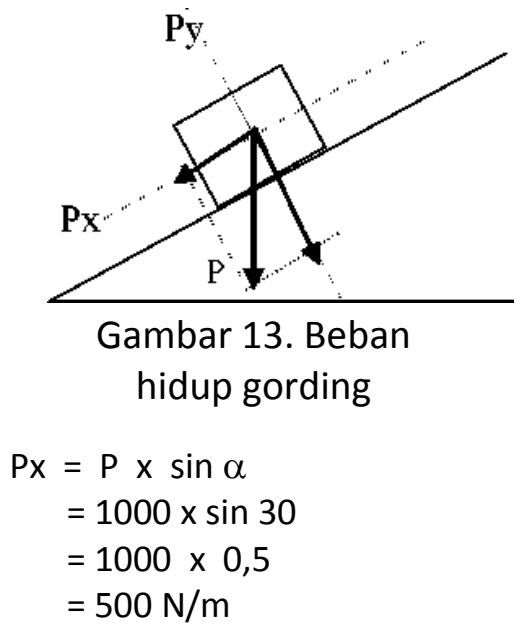




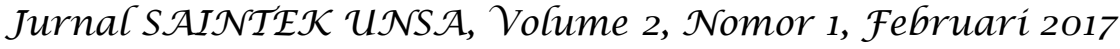

$$
\begin{aligned}
\text { Py } & =P \times \cos \alpha \\
& =1000 \times \cos 30 \\
& =1000 \times 0,866 \\
& =866,025 \mathrm{~N} / \mathrm{m}
\end{aligned}
$$

d. Perhitungan momen akibat beban hidup

Adapun gaya momen yamg bekerja pada gording adalah :

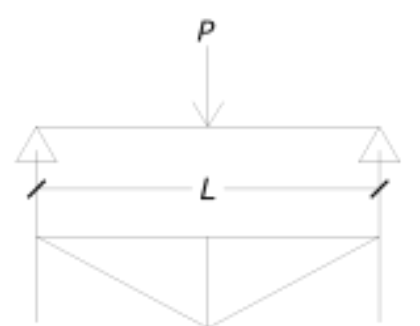

Gambar 14. Momen beban hidup

$$
\begin{aligned}
M \times 2 & =1 / 4 \times P \times \times L^{2} \\
& =1 / 4 \times 500 \times 3^{2} \\
= & 1125,000 \mathrm{Nm} \\
\text { My2 } & =1 / 4 \times P y \times L^{2} \\
& =1 / 4 \times 866,025 \times 3^{2} \\
& =1948,557 \mathrm{~N} / \mathrm{m}
\end{aligned}
$$

dimana :

$\mathrm{L}=$ Jarak antar kuda $-\mathrm{kuda}$

Beban angin diperhitungkan dengan menganggap adanya tekanan positif dan negatif (hisap). Tekanan angin yang bekerja tegak lurus pada bidang atap, dengan demikian tekanan angin hanya bekerja pada sumbu $Y$ sedangkan $X=0$.

Ada dua jenis beban angin yang harus ditinjau, yaitu :

1). Angin tekan Untuk tekanan angin hisap sesuai dengan pasal 4.2 ayat 2 yaitu $=40 \mathrm{~kg} / \mathrm{m2}=400 \mathrm{~N} / \mathrm{m2}$. Tekanan angin dengan sudut kemiringan $\alpha<60$ (PPURG 1987).

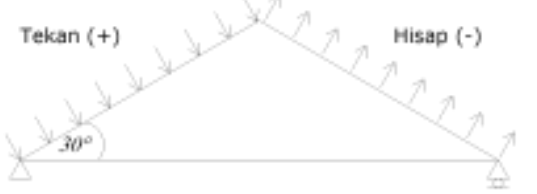

Gambar 15. Beban angin
Angin bekerja tegak lurus bidang atap dengan koefisien tiup dan hisap sudut atap $C=0,02(\alpha)-0.4$ (persamaan 2.21)

$$
\begin{aligned}
=0,02 \times 30-0.4 & =0,2 \\
\text { qx} & =0 \\
\text { qy } & =\mathrm{C} \times \omega \times \mathrm{L} \\
& =0,2 \times 400 \times 1,54 \\
& =123,168 \mathrm{~N} / \mathrm{m}
\end{aligned}
$$

dimana :

$\mathrm{L}=$ jarak antar gording $(\mathrm{m})$

$$
\begin{aligned}
& M \times 3=1 / 8 \times \text { qy } \times L^{2} \\
& \times 3^{2} \\
& M \times 3=1 / 8 \times 123,168 \\
& =138,564 \mathrm{Nm} \\
& \text { My3 }=0 \mathrm{Nm}
\end{aligned}
$$

2). Angin hisap

Angin yang bekerja keluar tegak lurus bidang atap dengan koefisien angin hisap $\mathrm{CH}=-0,4$ (PPURG 1987) $\mathrm{qx}=0$

qy $=\mathrm{CH} \times \omega \times \mathrm{L}$

$=-0,4 \times 400 \times 1,54$

$=-246,3363 \mathrm{~N} / \mathrm{m}$

dimana :

$\mathrm{L}=$ jarak antar gording $(\mathrm{m})$

e. Perhitungan momen akibat beban angin

$$
\begin{aligned}
M \times 3 & =1 / 8 \times \text { qy } \times L^{2} \\
M \times 3 & =1 / 8 \times-246,33 \times 3^{2} \\
& =-217,128 \mathrm{Nm}
\end{aligned}
$$

$\mathrm{My3}=0 \mathrm{Nm}$ dimana :

$\mathrm{L}$ = Jarak antar kuda - kuda

Didalam perhitungan hanya angin tekan saja yang diperhitungkan karena angin hisap hanya akan memperkecil tegangan pada batang.

f. Momen terfaktor

Momen terfaktor merupakan momen yang bekerja pada struktur yang menggunakan kombinasi beban menurut SNI $03-x x x-2000$

1). Kombinasi momen akibat sementara ( $D L+L L+$ Wtekan) 


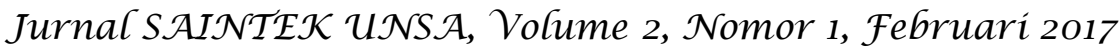

$$
\begin{aligned}
& \operatorname{Mux}=1,2 \mathrm{Mx}(\mathrm{D})+1,6 \mathrm{Mx}(\mathrm{L})+0,8 \\
& \text { (Wtekan) } \\
& \text { Mux }=1,2(464,513)+1,6(112,00)+0,8 \\
& (138,564) \\
& =2468,27 \mathrm{Nm} \\
& \text { Muy }=1,2 \mathrm{My}(\mathrm{D})+1,6 \mathrm{My}(\mathrm{L})+0,8 \\
& \text { (Wtekan) } \\
& \text { Muy }=1,2(804,560)+1.6(1948,56)+0,8 \\
& \text { (0.000) } \\
& =4083,16 \mathrm{Nm} \\
& \text { Mux }=1,2 \operatorname{Mx}(D)+1,6 M x(L)+0,8 \\
& \text { (Wisap) } \\
& \text { Mux }=1,2(464,513)+1.6(1125,00)+0,8 \\
& \text { (-277.128) } \\
& =2135,71 \mathrm{Nm} \\
& \text { Muy }=1,2 \operatorname{My}(D)+1,6 \mathrm{My}(L)+0,8 \\
& \text { (Wisap) } \\
& \text { Muy }=1.2(804,560)+1,6(1948.56)+0,8 \\
& \text { (0.000) } \\
& =4083,16 \mathrm{Nm}
\end{aligned}
$$

4). Momen inersia penampang

Merupakan momen lembam gording yang bekerja pada poros gording.

$$
\begin{aligned}
\mathrm{Ix} & =1 / 12 \times \mathrm{b} \times \mathrm{h}^{3} \\
& =1 / 12 \times 80 \times 100^{3}
\end{aligned}
$$$$
=6666666,67 \mathrm{~mm}^{4}
$$

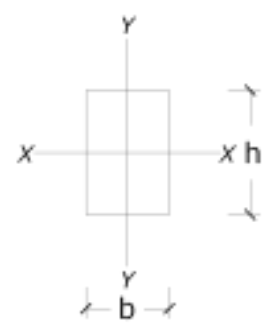

Gambar 16. Inersia penampang searah sumbu $x$

$$
\text { ly }=1 / 12 \times b^{3} \times h
$$

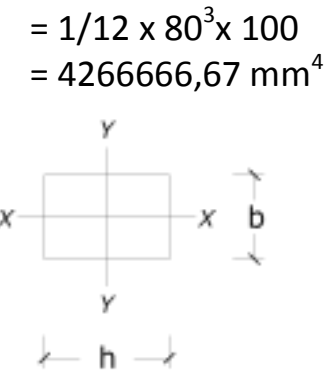

Gambar 17. Inersia penampang searah sumbu y

5). Momen statis penampang (S) Momen statis penampang momen yang bekerja pada gording :

Sx $=1 / 6 \times b \times h^{2}$

$$
=1 / 6 \times 80 \times 100^{2}
$$$$
=133333,33 \mathrm{~mm}^{3}
$$

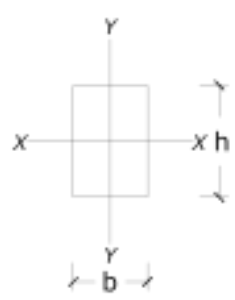

Gambar 18. Momen statis penampang searah sumbu $x$

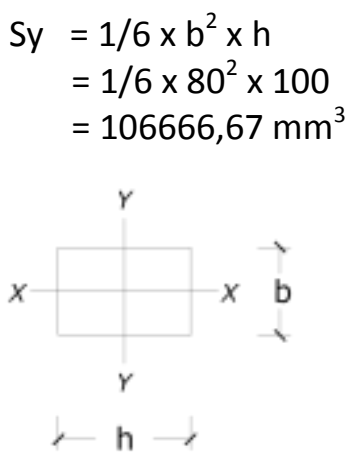

Gambar 19. Momen statis penampang searah sumbu y

Karena nilai banding penampang $d / b(100 / 80)=1,250<$ 2,00, maka balok tidak diperlukan pengekang lateral (SNI $03-x x x-$ 2000), $C_{1}=1.00$. nilai $C t$ diambil dalam kadar air kering dengan suhu $\mathrm{T}<38^{\circ}<{ }^{\circ} \mathrm{C}$ maka nilai $\mathrm{Ct}=$ 1.00. Untuk kayu dengan mutunya 


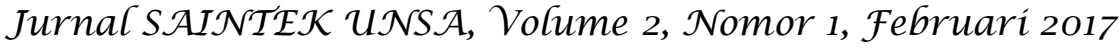

ditetapkan secara maksimal, $\mathrm{Cf}=$ 1.00 (SNI $03-\mathrm{xxX}-2000$ butir 5.6.2), faktor koreksi pengawetan kayu, Nilai Cpt $=1.00$ (SNI $03-x x x$ - 2000 butir 5.6.1). Faktor koreksi layan basah, untuk memperhitungkan kadar air masa layan pada balok kayu besar 125 $\mathrm{mm} \times 125 \mathrm{~mm}, \mathrm{Fb}=1.00$ nilai $\mathrm{C}_{\mathrm{M}}=$ $\mathrm{Fb} / \mathrm{Cf}=1.00 / 1.00=1.00<8 \mathrm{Mpa}$ maka $C_{M}=1.00$. factor reduksi tegangan untuk batang lentur, $\varphi b$ $=0.85$ dan factor waktu $(\lambda)$ pada kombinasi pembebanan $1.2(D)+$ $1.6(\mathrm{~L})+0.8(\mathrm{~W})$ maka $\lambda=0,8$

$\mathrm{Fbx}^{\prime}=\mathrm{Cm} \times \mathrm{Ct} \times \mathrm{Cpt} \times \mathrm{F}_{\mathrm{bx}}$ $=1 \times 1 \times 1 \times 30=30 \mathrm{Mpa}$

$\mathrm{M}_{\mathrm{x}}{ }^{\prime}=\mathrm{S}_{\mathrm{x}} \times \mathrm{F}_{\mathrm{bx}}$ $=133333,33 \times 30=4000000$

Mpa

$\mathrm{Fby}^{\prime}=\mathrm{Cm} \times \mathrm{Ct} \times \mathrm{Cpt} \times \mathrm{F}_{\text {by }}$ $=1 \times 1 \times 1 \times 30=30 \mathrm{Mpa}$

$M y^{\prime}=S_{x} \times F_{b y}$ $=106666,67 \times 30=3200000$

Mpa

6). Kontrol tegangan ( $\mathrm{DL}+\mathrm{LL}+$ Wtekan)

$\begin{aligned} \frac{\text { Mux }}{\lambda \phi_{\mathrm{b}} \mathrm{Mx}}+\frac{\text { Muy }}{\lambda \phi_{\mathrm{b}} \mathrm{Mx}} & <1.00 \\ \frac{24668,27}{0,8 \times 0,85 \times 4000000}+\frac{4083,16}{0,8 \times 0,85 \times 3200000} & <1.00 \\ 0,0028 & <1.00\end{aligned}$

7). Kontrol tegangan ( $\mathrm{DL}+\mathrm{LL}+$ Wisap)

$\frac{\text { Mux }}{\lambda \phi_{\mathrm{b}} \mathrm{Mx}}+\frac{\text { Muy }}{\lambda \phi_{\mathrm{b}} \mathrm{Mx}}<1.00$

(Persamaan 2.7)

$\begin{aligned} \frac{2135,71}{0,8 \times 0,85 \times 4000000}+\frac{4083,63}{0,8 \times 0,85 \times 3200000} & <1,00 \\ 0,0026 & <1,00\end{aligned}$

g. Lendutan pada gording

Berdasarkan SNI $03-x x x-2000$ lendutan yang diizinkan untuk konstruksi terlindung seperti gording, kasau, kusen adalah :

$\sigma$ maks $=1 / 200 \times \mathrm{L}$ berdasarkan persamaan (2.8)

$=1 / 200 \times 3000=15 \mathrm{~mm}$

1). Akibat beban mati gording (D) berdasarkan persamaan (2.9) Lendutan akibat beban hidup pada gording diperhitung dengan menggunakan persamaan 2.9

$$
f x=\begin{array}{ccccc}
5 & \times & \text { qy } & \times & L^{4} \\
\hline 384 & \times & E & \times & \text { IX }
\end{array}
$$

$$
\begin{aligned}
f x & =\frac{5 \times 417,06 \times 30004 \times 10^{-3}}{384 \times 13000 \times 6666667} \\
& =5,02 \times \mathrm{mm} \\
f y & =\frac{5 \times \mathrm{q} \times \times \mathrm{L}^{4}}{384 \times \mathrm{E} \times \mathrm{ly}} \\
f x & =\frac{5 \times 866,025 \times 30000^{4} \times 10^{-3}}{384 \times 13000 \times 4266667} \\
& =13,60 \mathrm{~mm}
\end{aligned}
$$

2). Akibat beban hidup gording $(P)$ Lendutan akibat beban hidup pada gording diperhitungkan dengan menggunakan persamaan 2.19

$$
\begin{aligned}
& f x=\begin{array}{ccccc}
1 & x & P x & x & L^{4} \\
\hline 48 & x & E & x & \text { Iy }
\end{array} \\
& f x=\begin{array}{cccccccc}
1 & \times & 500 & \times & 3000^{4} & \times & 10^{-3} \\
\hline 48 & \times & 13000 & \times & 6666667 & &
\end{array} \\
& =0,00325 \mathrm{~mm} \\
& \text { fy }=\begin{array}{lllll}
1 & x & P y & x & L^{4} \\
\hline 48 & x & E & x & \text { Ix }
\end{array}
\end{aligned}
$$

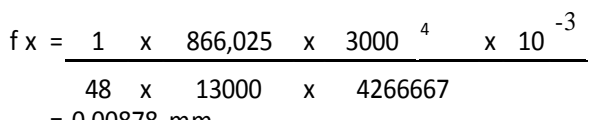

$$
\begin{aligned}
& =0,00878 \mathrm{~mm}
\end{aligned}
$$

3). Lendutan total gording

$$
\begin{aligned}
& F \text { total }=\sqrt{(F x)^{2}+(F y)^{2}} \\
& \quad=(5,03)^{2}+(13,61)^{2} \\
& =14,51 \mathrm{~mm}<15,00 \mathrm{~mm} .
\end{aligned}
$$




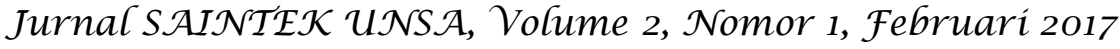

Dari perhitungan diatas dengan melihat hasil lendutan dan tegangan lentur yang terjadi bahwa dimensi kayu 8/10 cm dengan kelas kuat kayu kelas II dapat digunakan sebagai gording pada kontruksi atap rumah panggung.

Menghitung rangka kuda - kuda

a. Beban mati

- P1=P5(Beban mati pada gambar 20)

Berat penutup atap $=500 \mathrm{x}$

Jarak $\mathrm{AH} \times \cos 30$

$=500 \times 2,0 \times 0,866$

$=2598,076 \mathrm{~N}$

Beratgording $=0,08 \times 0,10 \times 7000$

$\times 3$

$=168,000 \mathrm{~N}$

Berat alat sambung $=25 \% \mathrm{x}$ 168,000

$=42,00 \mathrm{~N}$

Berat plafon + rangka $=2 \times 3 \times$

180

$=1080 \mathrm{~N}$

$\mathrm{qd}=2598.876+192.96+$

$42,000+1080$

$=3888,876 \mathrm{~N}$

Beban Tritisan

Berat penutup atap $=500 \mathrm{x}$

$3,00 \times \cos 30 \times$ Tritisan

$=500 \times 3,00 \times 0,866 \times 0,8$

q tritisan $=1039,230 \mathrm{~N}$

Beban total $(\mathrm{qd})=\mathrm{qd}+\mathrm{qt}$

$=3888,876+1039,230$

$=4927,307 \mathrm{~N}$

- $\mathrm{P} 2$ = P4 (Beban mati pada gambar 20)

Berat penutup atap $=500 \mathrm{x}$

Jarak $\mathrm{AH} \times \cos 30 \times 3$

$=500 \times 2,0 \times 0,866 \times 3$

$=2598,076 \mathrm{~N}$

Berat gording $=0.08 \times 0,10 \times$

$7000 \times 3$

$=168,00 \mathrm{~N}$

Berat alat sambung $=25 \% \mathrm{x}$

$168,00=42,00 \mathrm{~N}$

Berat plafon + rangka $=2 \times 3 \times$

$180=1080 \mathrm{~N}$ $q d=2598,876+168,00+42,00$

$+1080=3888,076 \mathrm{~N}$

- P3 (Beban mati pada gambar 20)

Berat penutup atap $=500 \mathrm{x}$

Jarak $\mathrm{HG} \times \cos 30$

$=500 \times 2,0 \times 0,866$

$=2598,876 \mathrm{~N}$

Berat gording $=0,08 \times 0,10 \times$

$7000 \times 3$

$=168,00 \mathrm{~N}$

Berat alat sambung $=25 \% \mathrm{x}$ 168,00

$=42,00 \mathrm{~N}$

Berat plafon + rangka $=2,00 \mathrm{x}$ $3,00 \times 180=1080 \mathrm{~N}$

$\mathrm{qd}=2598,076+168,00+$

$42,00+1080$

$=3888,076 \mathrm{~N}$

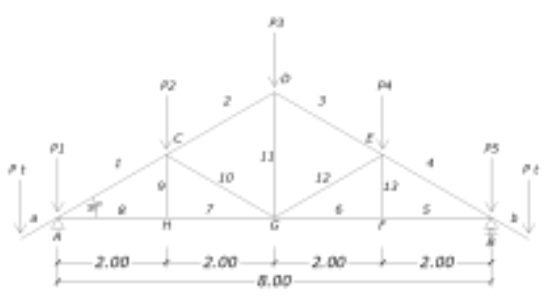

Gambar 20. Skema beban mati

dengan :

$\mathrm{P} 1=4927,307 \mathrm{~N}$

$\mathrm{P} 2=3888,076 \mathrm{~N}$

$\mathrm{P} 3=3888,076 \mathrm{~N}$

1. Menghitung gaya batang masing masing simpul dengan cara Analitis Reaksi tumpuan

$\mathrm{RA}=\mathrm{RB}$

$=1 / 2 \times \mathrm{P} 1+\mathrm{P} 2+\mathrm{P} 3+\mathrm{P} 4+\mathrm{P} 5$

$=1 / 2 \times 4927,307+3888,076+$

$3888,076+3888,076+4927,307$

$=10759,42 \mathrm{~N}$

Simpul A

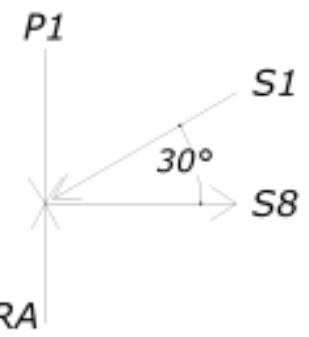




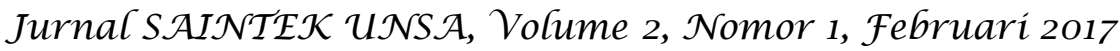

$\Sigma V=0$

$\mathrm{RA}-\mathrm{P} 1-\mathrm{S} 1 \cdot \sin 30=0$

$10759,421-4927,307-\mathrm{S} 1.0 .5=0$

$5832,114-\mathrm{S} 10.5=0$

S1 $=11664,229 \mathrm{~N}$

$\Sigma H=0$

$\mathrm{S} 8-\mathrm{S} 1 \cos 30=0$

$\mathrm{S} 8-11664,229 \times 0,866=0$

$\mathrm{S} 8-10101,518=0$

$\mathrm{S} 8=10101,518 \mathrm{~N}$

Simpul H

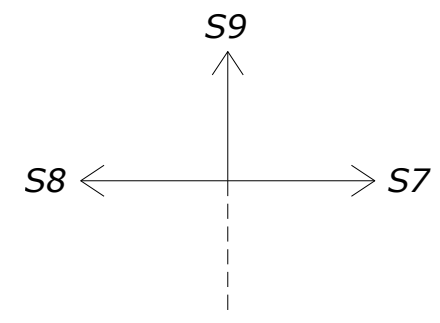

$\Sigma \mathrm{V}=0$

S9 $=0$

$\Sigma \mathrm{H}=0$

$\mathrm{S} 7-\mathrm{S} 8=0$

$\mathrm{S} 7=\mathrm{S} 8$

$\mathrm{S} 7=10101,518 \mathrm{~N}$

Simpul C

S1

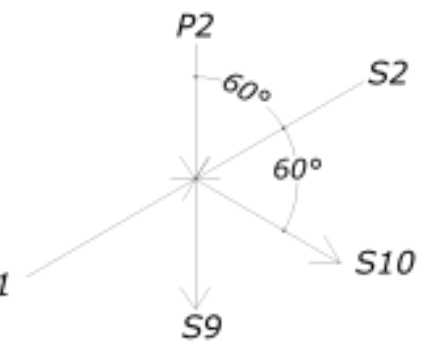

$\Sigma \mathrm{V}=0$

$\mathrm{S} 10 \sin 60-\mathrm{P} 2 \sin 60=0$

S10 $0,866-3888,076 \times 0,866=0$

S10 $0,866-3367,173=0$

$\mathrm{S} 10=3888,076 \mathrm{~N}$

$\Sigma \mathrm{H}=0$

$\mathrm{S} 1-\mathrm{S} 10 \cos 60-\mathrm{P} 2 \cos 60-\mathrm{S} 2=0$

$11664,23-3888,076 \times 0.5-$

$3888,076 \times 0.5-\mathrm{S} 2=0$

$\mathrm{S} 2=7776,152 \mathrm{~N}$

Simpul D

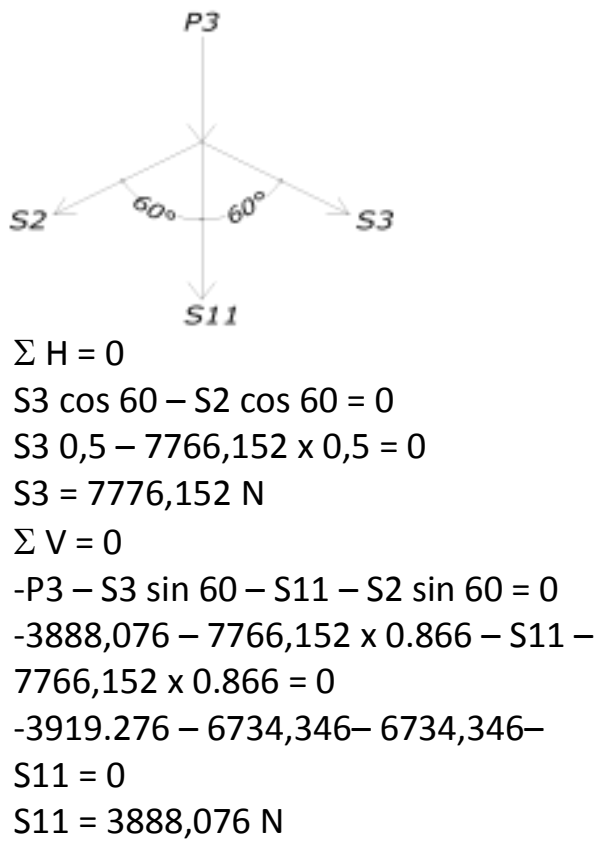

Menghitung gaya batang masing - masing simpul dengan cara Grafis.

Tabel 2. Hasil perhitungan gaya batang beban mati

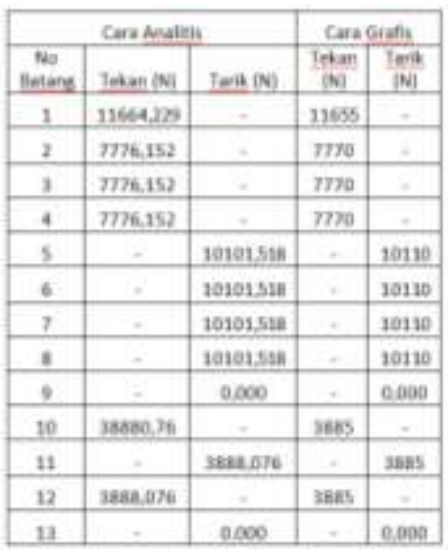

Beban hidup $(\mathrm{P})=100 \mathrm{~kg}=1000 \mathrm{~N}($ PPURG 1987)

$>\mathrm{P} 1=$ P5 (beban hidup yang bekerja pada atap dapat dilihat pada gambar 4.23)

Beban tritisan pada atap ditinjau $=$ $200 \mathrm{~kg}=2000 \mathrm{~N}$ (PPURG 1987)

$P$ total $=1000+2000$ $=3000 \mathrm{~N}$

$>\mathrm{P} 2=\mathrm{P} 3=1000 \mathrm{~N}$ ((beban hidup yang bekerja pada atap dapat dilihat pada gambar 4.23)

$>$ Beban yang diakibatkan oleh pekerja dan oleh pemadam kebakaran 


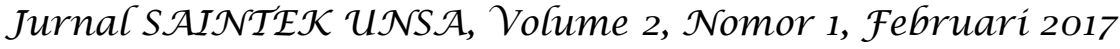

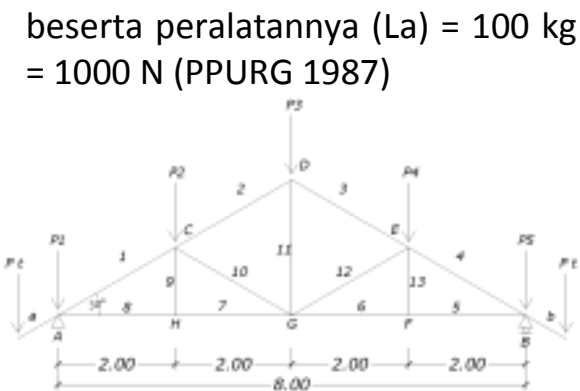

Gambar 21. Skema beban hidup

dengan :

$\mathrm{P} 1=3000 \mathrm{~N}$

$\mathrm{P} 2=1000 \mathrm{~N}$

$\mathrm{P} 3=1000 \mathrm{~N}$

1. Menghitung gaya batang masing masing simpul dengan cara analiti dengan menggunakan metode kestimbangan titik buhul.

Reaksi tumpuan

$\mathrm{RA}=\mathrm{RB}$

$=1 / 2 \times \mathrm{P} 1+\mathrm{P} 2+\mathrm{P} 3+\mathrm{P} 4+\mathrm{P} 5$

$=1 / 2 \times 3000+1000+1000+1000+$

3000

$=4500 \mathrm{~N}$

Simpul A

P1

S1

$30^{\circ}$

S8

$R A$

$\Sigma \mathrm{V}=0$

$\mathrm{RA}-\mathrm{P} 1-\mathrm{S} 1 . \sin 30=0$

$4500-3000-\mathrm{S} 1 \cdot 0,5=0$

$1500-\mathrm{S} 10,5=0$

$\mathrm{S} 1=3000 \mathrm{~N}$

$\Sigma \mathrm{H}=0$

$\mathrm{S} 8-\mathrm{S} 1 \cos 30=0$

$\mathrm{S} 8-3000 \times 0,866=0$

$\mathrm{S} 8-2598,076=0$

$\mathrm{S} 8=2598,076 \mathrm{~N}$

Simpul H

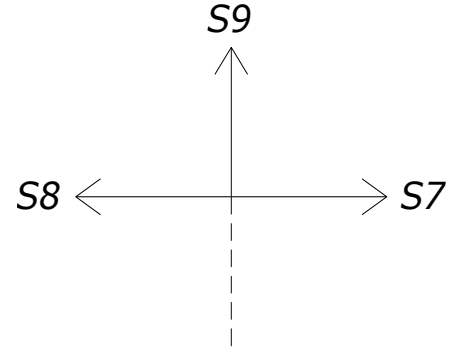

$\Sigma \mathrm{V}=0$

S9 $=0$

$\Sigma \mathrm{H}=0$

$\mathrm{S} 7-\mathrm{S} 8=0$

$\mathrm{S} 7=\mathrm{S} 8$

$\mathrm{S} 7=2598,076 \mathrm{~N}$

Simpul C

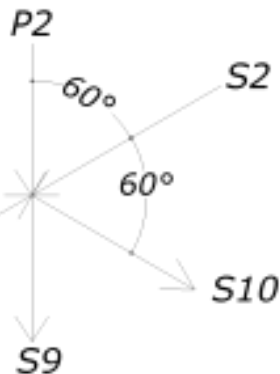

$\Sigma \mathrm{V}=0$

$\mathrm{S} 10 \sin 60-\mathrm{P} 2 \sin 60=0$

S10 $0,866-1000 \times 0,866=0$

S10 $0,866-866,025=0$

$\mathrm{S} 10=1000 \mathrm{~N}$

$\Sigma \mathrm{H}=0$

$\mathrm{S} 1-\mathrm{S} 10 \cos 60-\mathrm{P} 2 \cos 60-\mathrm{S} 2$

$=0$

$3000-1000 \times 0,5-1000 \times 0,5-$

$\mathrm{S} 2=0$

$\mathrm{S} 2=2000 \mathrm{~N}$

Simpul D

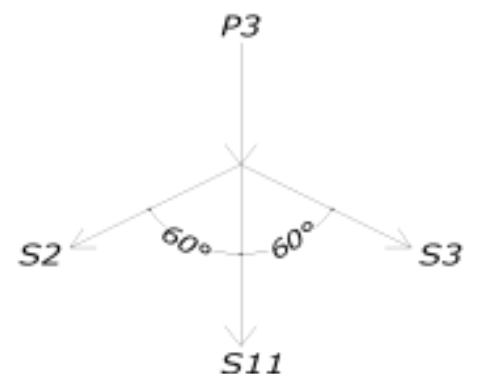

$\Sigma \mathrm{H}=0$

$\mathrm{S} 3 \cos 60-\mathrm{S} 2 \cos 60=0$

S3 $0,5-2000 \times 0,5=0$

$\mathrm{S} 3=2000 \mathrm{~N}$ 


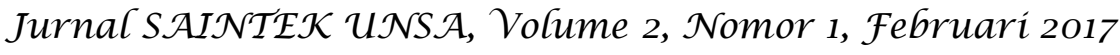

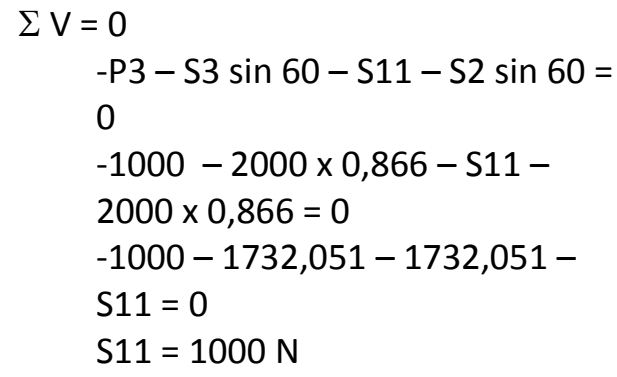

Menghitung gaya batang masing - masing simpul dengan cara Grafis.

Tabel 3. Hasil perhitungan gaya batang beban hidup

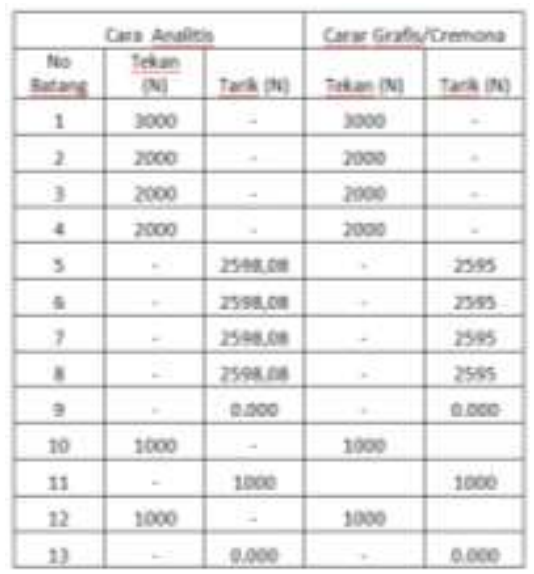

Beban angin

Beban angin merupakan beban yang diakibatkan oleh pergerakan angin yang mengenai atau melalui bagian dari struktur bangunan.

Adapun beban angin yang bekerja pada atap $\omega=40 \mathrm{~kg} / \mathrm{m}^{2}=400 \mathrm{~N} / \mathrm{m}^{2}$.

a. Angin tekan berdasarkan persamaan

$$
\begin{aligned}
C & =0.02 \alpha-0.4 \\
& =0.02 \times 30-0.4 \\
& =0.2
\end{aligned}
$$

b. Angin hisap

Kooefisien angin hisap $=-0.4($ PPURG 1987)

Adapun beban angin yang bekerja pada rangka atap adalah sebagai berikut :

$\mathrm{W} 1=0.2 \times \underline{1.54} \times 3 \times 400$

$\cos 30$

$=0.2 \times \underline{1.54} \times 3 \times 400$

0.866

$q w=426,667 \mathrm{~N}$
$W$ tritisan $=0.2 \times \underline{0,80} \times 3 \times 400$

$\cos 30$

$=0.2 \times \underline{0,8} \times 3 \times 4000.866$

$\mathrm{Wt}=221,703 \mathrm{~N}$

$\mathrm{W}$ total $=\mathrm{qw}+\mathrm{W}$ tritisan

$=426,667+221,703$

$=648,369 \mathrm{~N}$

$\mathrm{W} 2=0.2 \times \underline{1,54} \times 3 \times 400$

$\cos 30$

$=0.2 \times \underline{1,54} \times 3 \times 400$

0.866

$=426,667 \mathrm{~N}$

W3 $=0,2 \times \underline{1.54} \times 3 \times 400$ $\cos 30$

$=0.2 \times \underline{1.54} \times 3 \times 400$

0.866

$=426.667 \mathrm{~N}$

$\mathrm{W} 4=-0.4 \times \underline{1.54} \times 3 \times 400$ $\cos 30$

$=-0.4 \times \underline{1.54} \times 3 \times 400$

0.866

$=853.333 \mathrm{~N}(-)$

W5 $=-0.4 \times \underline{1.54} \times 3 \times 400$ $\cos 30$

$=-0.4 \times \underline{1.54} \times 3 \times 400$ 0.866

$=853.333 \mathrm{~N} \mathrm{(-)}$

W6 $=-0.4 \times \underline{1.54} \times 3 \times 400$ $\cos 30$

$=-0.4 \times \underline{1.54} \times 3 \times 400$ 0,866

$=853,133 \mathrm{~N}(-)$

W tritisan $=-0,4 \times \underline{0,80} \times 3 \times 400$ $\cos 30$

$=-0.4 \times \underline{0,80} \times 3 \times 400$

0,866

$=443,405 \mathrm{~N}(-)$

Wtotal $=853,133+443,405$

$=1296,738 \mathrm{~N}$

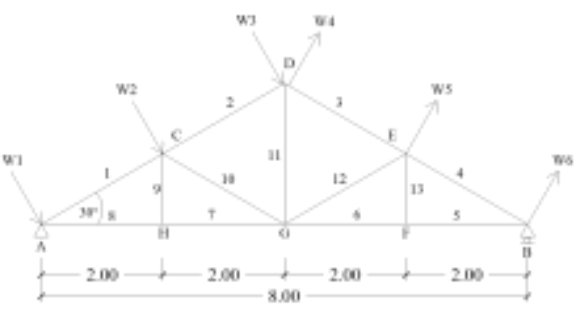

Gambar 22. Skema beban angina

dengan :

$\mathrm{WI}=648,369 \mathrm{~N}$

$\mathrm{W} 2=426,667 \mathrm{~N}$ 


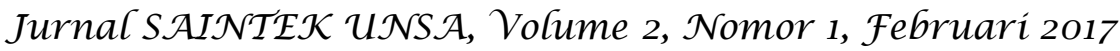

$$
\begin{aligned}
& W 3=426,667 \mathrm{~N} \\
& W 4=853,333 \mathrm{~N} \\
& W 5=853,333 \mathrm{~N} \\
& W 6=1296,738 \mathrm{~N}
\end{aligned}
$$

1. Menghitung gaya batang masing masing simpul dengan cara analitis dengan menggunakan metode kesetimbangan titik buhul.

Reaksi tumpuan

$\Sigma \mathrm{MB}=0$

VA $\times 8-W 1 \sin 60 \times 8-W 2 \sin 60 \times 6$ $+W 2 \cos 60 \times 1.155-W 3 \sin 60 \times 4+$ $W 3 \cos 60 \times 2,31+W 4 \sin 60 \times 4+W 4$ $\cos 60 \times 2.31+W 5 \sin 60 \times 2+W 5 \cos$ $60 \times 1.15$

VA $\times 8-648,369 \times 0,866 \times 8-426,667$ $\times 0,866 \times 6+426,667 \times 0,5 \times 1,15-$ $426,667 \times 0,866 \times 4+426,667 \times 0,5 \times$ $2,31+853,333 \times 0,866 \times 4+853,333 \times$ $0,5 \times 2,31+853,333 \times 0,866 \times 2,00+$ $853,333 \times 0,5 \times 1,15=0$

$V A=\underline{-1536,000}=-192,000 \mathrm{~N}$ 8

$\Sigma \mathrm{MA}=0$

$-\mathrm{VB} \times 8-\mathrm{W} 6 \sin 60 \times 8-\mathrm{W} 5 \sin 60 \times 6$ $+W 2 \sin 60 \times 6+W 5 \cos 601,15-W 4$ $\sin 60 \times 4+W 4 \cos 60 \times 2,31+W 3 \sin$ $60 \times 4+W 3 \cos 60 \times 2,31+W 2 \sin 60$ $x 2,00+W 2 \cos 60 \times 1,15=0$

- VB $\times 8-1296,738 \times 0,866 \times 8-$ $853,333 \times 0,866 \times 6+853,333 \times 0,5 \times$ $1,15-853,333 \times 0,866 \times 4+853,333 \times$ $0,5 \times 2,31+426,667 \times 0,866 \times 4+$ $426,667 \times 0.5 \times 2,31+426,667 \times 0,866$ $\times 2+426,667 \times 0,5 \times 1,15=0$

$V B=\underline{-11940,100}=1492,513 \mathrm{~N}$ $-8$

Kontrol hasil perhitungan

$\mathrm{VA}+\mathrm{VB}=\mathrm{W} 1 \sin 60+\mathrm{W} 2 \sin 60$ $+W 3 \sin 60+W 4 \sin 60+W 5 \sin 60+$ W6 $\sin 60$ $1071,562=-648,369 \times 0,866+(-$ $426,667) \times 0,866+(-426,667) \times 0,866$ $+853,333 \times 0,866++853,333 \times 0.866$ $+1296,738 \times 0.866$ $1300,513=1300,513$ OK $\Sigma \mathrm{MH}=0$
$\mathrm{HA}+\mathrm{W} 1 \cos 60+\mathrm{W} 2 \cos 60+\mathrm{W} 3 \cos$ $60+W 4 \cos 60+W 5 \cos 60+W 6 \cos$ 60

$\mathrm{HA}=647,369 \times 0,5+426,667 \times 0,5+$ $426,667 \times 0,5+853,333 \times 0,5+$ $853,333 \times 0,5+1296,738 \times 0,5$ $\mathrm{HA}=324,185+213,333+213,33+$ $426,667+426,667+648,369$ $\mathrm{HA}=2253 \mathrm{~N}$

Simpul A

W1

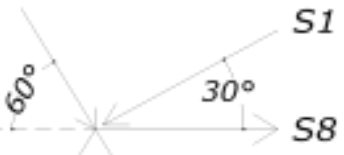

VA

$\Sigma \mathrm{V}=0$

$\mathrm{S} 1 \sin 30-\mathrm{VA}-\mathrm{W} 1 \sin 60$

$S 1=\frac{-192,000+648,39 \times 0.866}{0,866}$

$\mathrm{S} 1=339,802 \mathrm{~N}$

$\Sigma \mathrm{H}=0$

$\mathrm{S} 8-\mathrm{HA}+\mathrm{W} 1 \cos 60+\mathrm{S} 1 \cos 30$

$=0$

$\mathrm{S} 8=\mathrm{HA}-\mathrm{W} 1 \cos 60-\mathrm{S} 1 \cos 30$

$\mathrm{S} 8=2253-324,185-294,277$

$\mathrm{S} 8=1634,092 \mathrm{~N}$

Simpul $\mathrm{H}$

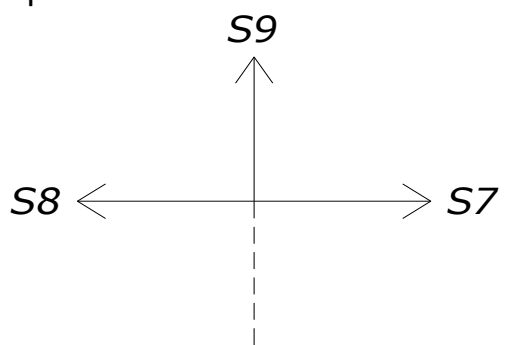

$\Sigma \mathrm{V}=0$

S9 $=0$

$\Sigma \mathrm{H}=0$

$\mathrm{S} 7-\mathrm{S} 8=0$

$\mathrm{S} 7=\mathrm{S} 8$

$\mathrm{S} 7=1634,092 \mathrm{~N}$ 


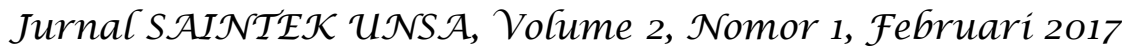

Simpul C

W2

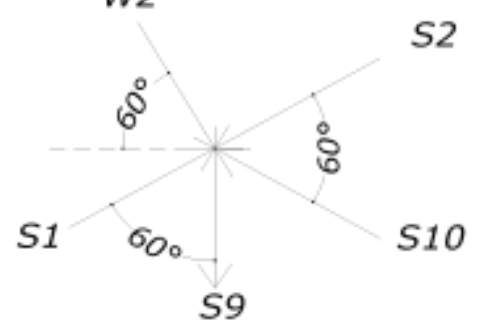

$\Sigma \mathrm{V}=0$

$\mathrm{W} 2 \sin 60-\mathrm{S} 2 \sin 60-\mathrm{S} 1 \sin$

$60-\mathrm{S} 10 \sin 60=0$

$426,667 \times 0,866-\mathrm{S} 2 \times 0,866-$

$\mathrm{S} 10 \times 0,866=0$

$369,504-\mathrm{S} 2 \times 0,866-\mathrm{S} 10 \mathrm{x}$

$0,866=0$

$\mathrm{S} 10 \times 0,866-\mathrm{S} 2 \times 0,866=-$

369,50

S10 + S2 $=426,667$ Pers 1

$\Sigma \mathrm{H}=0$

$\mathrm{W} 2 \cos 60-\mathrm{S} 2 \cos 60-\mathrm{S} 1$ $\cos 60-\mathrm{S} 10 \cos 60=0$

$426,667 \times 0,50-\mathrm{S} 2 \times 0,5-$ $339,802 \times 0,5-\mathrm{S} 10 \times 0,5=0$

$213,333-\mathrm{S} 2 \times 0,5-169,901-$ $\mathrm{S} 10 \times 0,5=0$

$\mathrm{S} 2 \times 0,5-\mathrm{S} 10 \times 0,5=213,333$

$+169,901$

$\mathrm{S} 10-\mathrm{S} 2=\underline{383,324}$

0,5

$\mathrm{S} 10-\mathrm{S} 2=766,468 \mathrm{~N}$....Pers II

Dari persamaan I dan II

$\mathrm{S} 10+\mathrm{S} 2=426,667$

$\underline{\mathrm{S} 10-\mathrm{S} 2=766,468 \pm}$

$2 \mathrm{~S} 10=1193,193$

$\mathrm{S} 10=\frac{1193,193}{2}$

2

$\mathrm{S} 10=596,968 \mathrm{~N}$

Dari persamaan I

$\mathrm{S} 10+\mathrm{S} 2=426,667$

$596,968+\mathrm{S} 2=426,667$

S2 $=596,968-426,667$

$\mathrm{S} 2=169,901 \mathrm{~N}$
Simpul D

W3

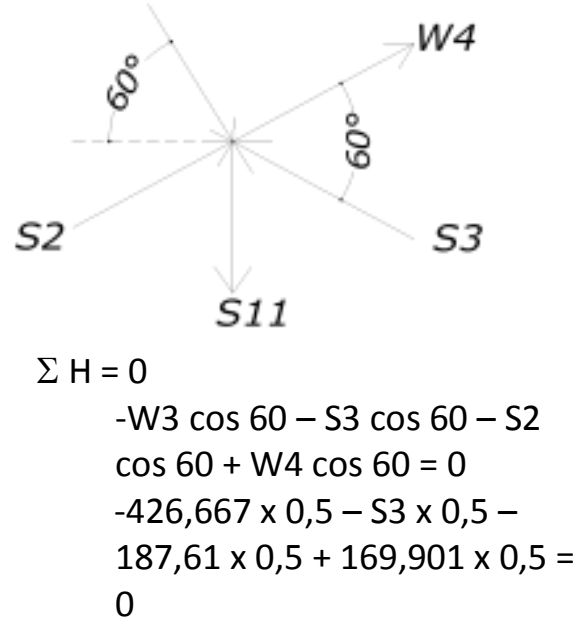

$-213,333-\mathrm{S} 3 \times 0,5-84,950+$

$426,667=0$

S3 $\times 0,5=298,284$

S3 $=\underline{298,284}$

0,5

$\mathrm{S} 3=596,568 \mathrm{~N}$

$\Sigma \mathrm{V}=0$

-W3 $\sin 60-\mathrm{S} 3 \sin 60+\mathrm{S} 11+$ $\mathrm{S} 2 \sin 60+\mathrm{W} 4 \sin 60=0$

$-426,667 \times 0,866-596,568 \times$

$0,866+\mathrm{S} 11+187,610 \times 0,866$

$+853,33 \times 0,866=0$

$-369,504-516,643+\mathrm{S} 11+$

$147,643+739,008=0$

$\mathrm{S} 11=739,008 \mathrm{~N}$

Simpul G

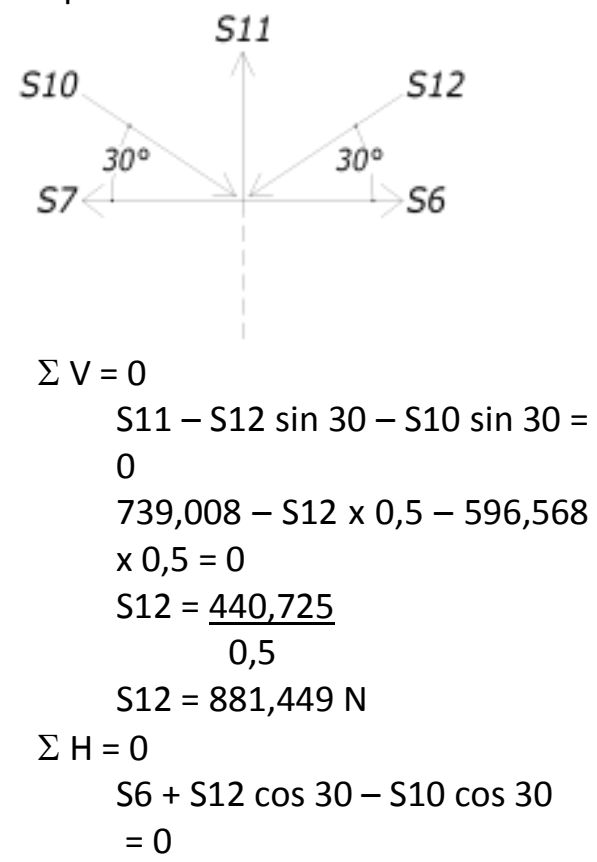


S6 + 881,449 $\times 0,866-$

$596,568 \times 0,866=0$

$\mathrm{S} 6=763,357+516,643$

$\mathrm{S} 6=1280,00 \mathrm{~N}$

Simpul $\mathrm{F}$

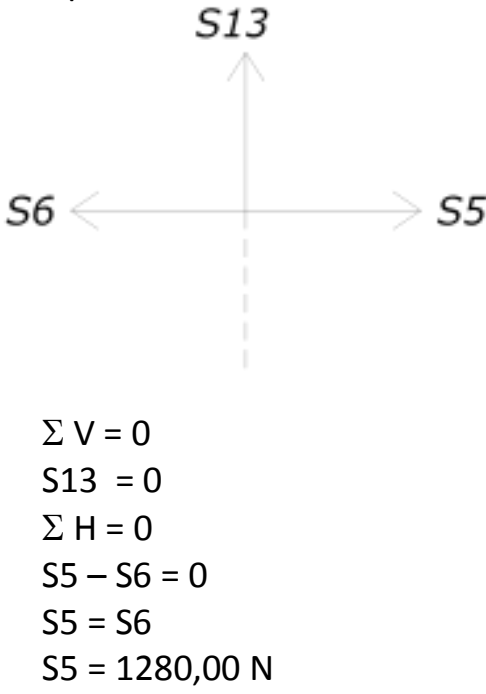

\section{Simpul E}

S3

$$
\begin{aligned}
& S 120_{S 13}^{60^{\circ}} S 4 \\
& \Sigma \mathrm{V}=0 \\
& \mathrm{~W} 5 \sin 60-\mathrm{S} 4 \sin 60-\mathrm{S} 13- \\
& \mathrm{S} 12 \sin 60=0 \\
& 853,333 \times 0,866-S 4 \times 0,866- \\
& 0-881,449 \times 0,866=0 \\
& 739,008-S 4 \times 0,866-763,357 \\
& =0 \\
& \text { S4 } \times 0,866=739,008+763,357 \\
& \mathrm{~S} 4=\underline{1502,366} \\
& 0,866 \\
& \mathrm{~S} 4=1734,783 \mathrm{~N}
\end{aligned}
$$

\begin{tabular}{|c|c|c|c|c|}
\hline \multirow{2}{*}{ Po } & \multicolumn{2}{|c|}{ Cons Ansaltis } & \multicolumn{2}{|c|}{ Cora Gratls } \\
\hline & $\frac{\operatorname{Tat} m}{(\mathrm{~N})}$ & Tre (N) & $\frac{10 k+n}{(x)}$ & $\tan (x)$ \\
\hline 1 & 235.sany & + & 740,90 & $=$ \\
\hline$\gamma$ & $160.900 \mathrm{I}$ & $*$ & 9ae,ee & $*$ \\
\hline 3 & 396.565 & $=$ & 246.00 & $=$ \\
\hline 4 & $1734=1$ &. & 260.60 & $=$ \\
\hline 5 & $=$ & 1210,000 & - & 20010 \\
\hline 6 & $=$ & 1230000 & $=$ & 260,00 \\
\hline 7 & $=$ & 1220000 & $=$ & 102000 \\
\hline 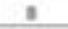 & $=$ & 104002 & + & 1020,00 \\
\hline 9 & $=$ & 0000 & $=$ & 0.000 \\
\hline 10 & $\operatorname{san} 445$ & 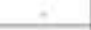 & $50 a, 00$ & - \\
\hline 11 & $=$ & $m 9.003$ & $=$ & 240,00 \\
\hline 12 & 191.44 & $*$ & 940,00 & $=$ \\
\hline 11 & $=$ & 0000 & $=$ & \\
\hline
\end{tabular}

2. Menghitung gaya batang masing masing simpul dengan cara Grafis.
Tabel 4. Hasil perhitungan gaya batang beban angin

Tabel 5. Kombinasi hasil pembebanan gaya batangberdasarkan SK SNI - $03-x x x 2002$

( Tata Cara Perencanaan Struktur Kayu Untuk Bangunan Gedung )

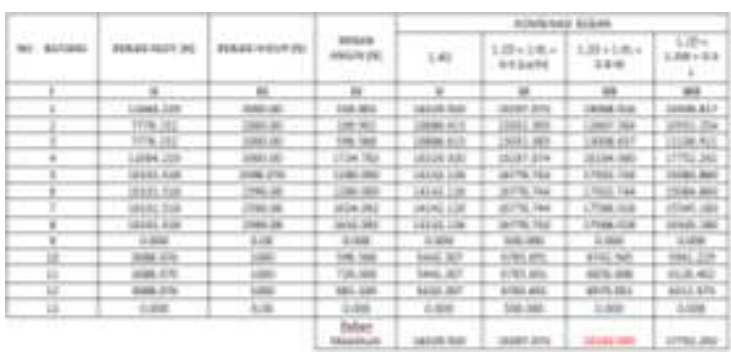

Menghitung dimensi batang

Pada konstruksi kuda - kuda di bagi menjadi dua kriteria batang struktur yaitu :

Merencanakan batang tekan (Batang 1, $2,3,4,10,12$ )

Batang tekan merupakan batang dari suatu rangka batang pada bangunan yang menerima tekan searah panjang batang.

Data kayu yang digunakan yaitu dengan kode mutu kayu = E14 (SNI $03-$ xxx - 2000)

Dicoba menggunakan kayu dengan kuat kayu kelas II dengan ukuran 60/120 mm.

$$
\begin{aligned}
& \mathrm{b}=60 \mathrm{~mm} \\
& \mathrm{~h}=120 \mathrm{~mm} \\
& \text { kuat tekan sejajar serat } \\
& (\mathrm{Fc})=30 \mathrm{Mpa} \\
& \mathrm{Ew}=13000 \mathrm{Mpa} \\
& \text { Faktor reduksi }(\varphi)=0.9 \\
& \mathrm{Ct} \quad=1.00
\end{aligned}
$$

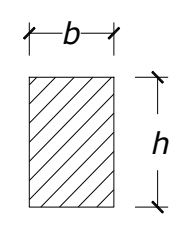

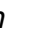




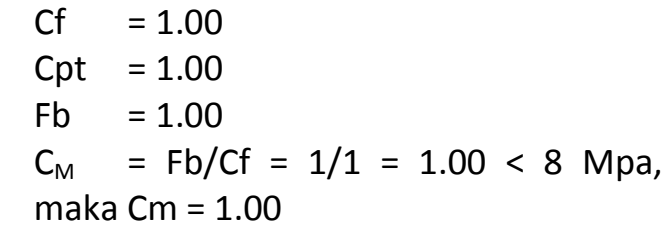

Faktor tahanan stabilitas $(\varphi s)=0.85$

Faktor tahanan tekan $(\varphi c)=0.90$

Faktor waktu $(\lambda)=0.80$

$c=0.80$

Kuat tekan sejajar serat $(\mathrm{Fc})$

$\mathrm{Fc}=30 \times 0,9=27 \mathrm{Mpa}$

$\mathrm{Ew}=13000 \mathrm{Mpa}$

1.Menghitung faktor beban

berdasarkan persamaan (2.13)

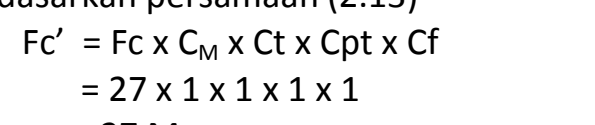$$
=27 \mathrm{Mpa}
$$

$\mathrm{Pc}^{\prime}=\mathrm{A}$ bruto $\times \mathrm{Fc}^{\prime}$

$=60 \times 120 \times 27$

$=194400 \mathrm{Mpa}$

$\mathrm{E}_{05}=0,69 \times \mathrm{Ew}$

$=0,69 \times 13000$

$=8970 \mathrm{Mpa}$

$\mathrm{Pe}=\frac{\mathrm{p}^{2} \times \mathrm{E}_{05} \times \mathrm{A}}{\frac{\mathrm{Ke} \times \mathrm{L}}{\mathrm{r}}}$

$r=0.289 \times b$

$=0.289 \times 60$

$=17,34$

$\mathrm{Pe}=\frac{3.14^{2} \times 8970 \times 7200}{\frac{1 \times 3000}{17,34}}$

$=122908,185 \mathrm{~N}$

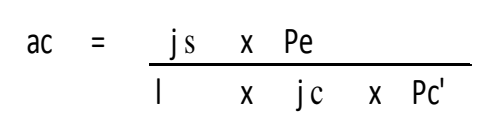$$
a c=\frac{0,85 \times 122908,185}{0,8 \times 0,9 \times 194400}=0,746
$$

$c p=\frac{+a c}{2 c}-\sqrt{\frac{1+a c^{2}}{2 c}}-\frac{a c}{c}$

$$
\begin{aligned}
C p & =\frac{1+0,721}{1,6}-\sqrt{\frac{1+0,746}{1,6}} \cdot \frac{0,746}{0,8} \\
& =0,151 \\
P^{\prime} & =C p \times P c \\
& =0,151 \times 194400 \\
& =29451,463 \mathrm{~N} \\
\mathrm{Pu} & <\lambda \times \varphi \mathrm{C} \times \mathrm{P}^{\prime} \\
& 20690,900<0.80 \times 0.90 \times 29451,463 \\
& 20184,900<21205,053 \mathrm{~N} \\
& \text { Berdasarkan perhitungan diatas }
\end{aligned}
$$
bahwa dimensi kayu 6/12 cm dengan klasifikasi kuat kayu kelas II dapat digunakan sebagai batang tekan pada konstruksi kuda - kuda rumah panggung.

Dimensi batang tarik (Batang 5, 6, 7, 8, 11, 13)

Batang tarik merupakan batang dari struktur yang dapat menahan pembebanan tarik yang bekerja searah dengan sumbunya.

1. Menghitung kuat tarik sejajar (Ft//) Faktor tahanan serat $=0.80$

Faktor kuat tarik sejajar serat (Ft//) $=28 \mathrm{Mpa}$

$\mathrm{Ft}=0.80 \times 28=22 \mathrm{Mpa}$

2. Menghitung tahanan tarik terkoreksi

$$
\begin{aligned}
& \mathrm{Ct}=1.00 \\
& \mathrm{Cf}=1.00 \\
& \mathrm{Cpt}=1.00 \\
& \mathrm{Fb}=1.00 \\
& \mathrm{C}_{\mathrm{M}}=\mathrm{Fb} / \mathrm{Cf}=1 / 1=1.00<8 \mathrm{Mpa}, \\
& \text { maka } \mathrm{Cm}=1.00 \\
& \text { Faktor koreksi tahan api }(\mathrm{Crt})=1.00 \\
& \mathrm{~T}^{\prime}=\mathrm{F}^{\prime} \mathrm{t} \times \mathrm{An} \\
& \mathrm{T}^{\prime}=\mathrm{Cm} \times \mathrm{Ct} \times \mathrm{Cpt} \times \mathrm{Cf} \times \mathrm{Crt} \times \mathrm{Ft} \times \mathrm{An} \\
& \mathrm{T}^{\prime}=1 \times 1 \times 1 \times 1 \times 1 \times 22 \times \mathrm{An}
\end{aligned}
$$

3. Menghitung kebutuhan luas

- Kebutuhan luas neto (An)

$\mathrm{Tu}<\lambda \times \boldsymbol{x}$ t $\times \mathrm{T}^{\prime}$ $20184,, 900<0.80 \times 0.80 \times 1 \times 1 \times$ $1 \times 1 \times 1 \times 22 \times A n$ $20184,, 900<14,34 \times$ An $A n=\underline{20690,65}=1443,654 \mathrm{~mm}^{2}$ 14,34

- Kebutuhan luas bruto (Ag) $\mathrm{Ag}=1.25 \times \mathrm{An}=1.25 \times 1443,654$ 


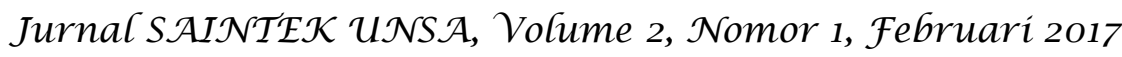

$$
=1804,082 \mathrm{~mm}^{2}
$$

4. Kontrol tahanan tarik

Dicoba menggunakan kayu dengan kuat kayu kelas II dengan ukuran $60 / 120 \mathrm{~mm}$.

$\mathrm{b}=60 \mathrm{~mm}$

$\mathrm{h}=120 \mathrm{~mm}$

$\mathrm{Ag}=60 \times 120=7200$

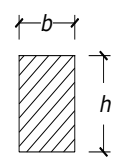

$\mathrm{Tu}<\lambda \times \varphi \mathrm{t} \times \mathrm{F}^{\prime} \mathrm{t} \times$ An (persamaan 2.15)

$\mathrm{Tu}<0.80 \times 0.80 \times 22 \times(75 \% \times 7200)$ $20184,, 900<58060,800 \mathrm{~N}$.

Berdasarkan perhitungan diatas bahwa dengan kelas kuat kayu kelas II dengan ukuran $6 / 12 \mathrm{~cm}$ dapat digunakan sebagai batang tarik pada kontruksi kuda - kuda rumah panggung.

Tabel 6. Rekapitulasi dimensi batang dari hasil perhitungan kontruksi

\begin{tabular}{|c|c|c|c|}
\hline $\begin{array}{c}\text { No } \\
\text { Batang }\end{array}$ & $\begin{array}{c}\text { Mutu } \\
\text { Kayu }\end{array}$ & $\begin{array}{c}\text { Kelas kuat } \\
\text { Kayu }\end{array}$ & Dimensi \\
\hline 1 & E14 & Kelas II & $6 / 12$ \\
2 & E14 & Kelas II & $6 / 12$ \\
3 & E14 & Kelas II & $6 / 12$ \\
4 & E14 & Kelas II & $6 / 12$ \\
5 & E14 & Kelas II & $6 / 12$ \\
6 & E14 & Kelas II & $6 / 12$ \\
7 & E14 & Kelas II & $6 / 12$ \\
8 & E14 & Kelas II & $6 / 12$ \\
9 & E14 & Kelas II & $6 / 12$ \\
10 & E14 & Kelas II & $6 / 12$ \\
11 & E14 & Kelas II & $6 / 12$ \\
12 & E14 & Kelas II & $6 / 12$ \\
13 & E14 & Kelas II & $6 / 12$ \\
\hline
\end{tabular}

Menghitung beban balok

Balok lantai merupakan konsruksi kayu terbawah untuk menopang lantai.

1 Perhitungan beban lantai

a. Beban mati

Berat papan lantai kayu sederhana $=40 \mathrm{~kg} / \mathrm{m}^{2}$

$=400 \mathrm{~N} / \mathrm{m}^{2}$

Berat papan dinding kayu $=40$ $\mathrm{kg} / \mathrm{m}^{2}=400 \mathrm{~N} / \mathrm{m}^{2}$

$$
\text { q total }=400+400
$$$$
=800 \mathrm{~N} / \mathrm{m}^{2}
$$

c. Beban hidup
Beban hidup untuk lantai dan rumah sederhana $(\mathrm{ql})=125 \mathrm{~kg} / \mathrm{m}^{2}$ $=1250 \mathrm{~N} / \mathrm{m}^{2}$

Beban berfaktor $=1.2 \mathrm{D}+1.6 \mathrm{~L}$

$=1,2(800)+1,6(1250)$

$=2960 \mathrm{~N} / \mathrm{m}$

Perhitungan beban hidup pada lantai dengan melihat skema lantai pada gambar 23.

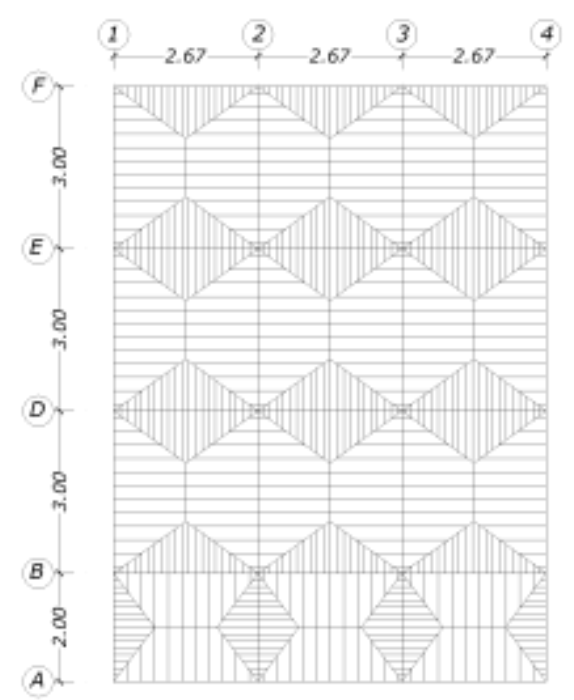

$$
\begin{aligned}
& \text { Gambar 23. Skema } \\
& \text { beban lantai }
\end{aligned}
$$

Analisa pembebanan yang bekerja

a. Beban Segitiga

$>$ Perhitungan Heq untuk portal melintang berdasarkan persamaan (2.22)

$$
\begin{aligned}
\text { Heq } & =1 / 3 . \mathrm{Lx} \\
& =1 / 3 \times 2,67=0,889 \mathrm{~m}
\end{aligned}
$$

$>$ Perhitungan Heq untuk portal memanjang berdasarkan persamaan (2.22)

$$
\begin{aligned}
\text { Heq } & =1 / 3 . \text { Lx } \\
& =1 / 3 \times 2,00=0,667 \mathrm{~m}
\end{aligned}
$$

> Beban merata lantai akibat beban segitiga

$q$ total $=0,667 \times 2960+0,889 \times 2960$

$$
=4604 \mathrm{~N} / \mathrm{m}
$$

b. Beban Trapesium

$>$ Perhitungan Heq untuk portal memanjang (persamaan 2.23)

Untuk bentang 3,00 meter Heq $=1 / 6$. Lx. $\left(3-4(\mathrm{Ix} / 2 . \text { Ly })^{2}\right.$ $=1 / 6 \times 2,67\left(3-4(2,67 / 2 \times 3,0)^{2}\right.$ $=0,543$ meter 


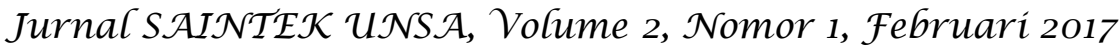

Perhitungan Heq untuk portal melintang (persamaan 2.23) Untuk bentang 2,67 meter Heq $=1 / 6$. Lx. $\left(3-4(\mathrm{Ix} / 2 . \text { Ly })^{2}\right.$ $=1 / 6 \times 3,00\left(3-4(3,00 / 2 \times 2,67)^{2}\right.$

$=0,234$ meter q ekivalen $=0,543 \times 2960+0,234 \times$ $2960=2302 \mathrm{~N} / \mathrm{m}$

q total beban lantai $=4604+2302$ $=6906 \mathrm{~N}$

c. Analisis dimensi balok

Analisi balok lantai diperhitung dari beban total lantai (q ekivalen) yang bekerja pada lantai rumah panggung.

1). Menghitung tegangan lentur balok Momen lentur maksimum $=\frac{w l^{2}}{8}=6906 \times 3^{2}=7769 \mathrm{Nm}$

Kontrol tahanan lentur berdasarkan persamaan (2.28)

$$
\begin{aligned}
\mathrm{F}^{\prime} \mathrm{bx} & =\mathrm{Fb} \times \mathrm{C}_{\mathrm{M}} \times \mathrm{Ct} \times \mathrm{Cpt} \times \mathrm{Cf} \\
& =30 \times 1 \times 1 \times 1 \times 1 \\
& =30 \mathrm{Mpa}
\end{aligned}
$$

Modulus panampang (Sx)

Dicoba ukuran kayu $8 / 12$

$$
\mathrm{b}=80 \mathrm{~mm}
$$

$\mathrm{h}=120 \mathrm{~mm}$

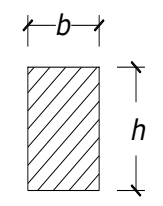

$$
S x=\frac{b d^{2}}{6}=\frac{80 \times 120^{2}}{6}=192000
$$

Tahanan momen lentur terkoreksi $\left(\mathrm{Mx}^{\prime}\right) \mathrm{Mx}^{\prime}=\mathrm{Sx} . \mathrm{Fbx}$

$$
=192000 \times 30=5760000 \mathrm{Nm}
$$

$>$ Momen lentur terfaktor berdasarkan persamaan (2.24)

$\mathrm{Mu}<\lambda$. $\phi \mathrm{b} . \mathrm{Mx}^{\prime}$

$7769<0,6 \times 0,85 \times 5760000$

$7769<2937600 \mathrm{Nm}$

2). Gaya geser maksimum

$=\frac{\mathrm{wl}}{8}=7769 \times 3=2590 \mathrm{Nm}$

Kontrol tahanan geser $\left(F^{\prime} v\right)$

$\mathrm{F}^{\prime} \mathrm{v}=\mathrm{Fv} \times \mathrm{C}_{\mathrm{M}} \times \mathrm{Ct} \times \mathrm{Cpt}$

$=4,9 \times 1 \times 1 \times 1$

$=4,9 \mathrm{Mpa}$

Tahanan geser terkoreksi ( $\left.\mathrm{V}^{\prime}\right)$ berdasarkan persamaan (2.29)

$$
\begin{aligned}
V^{\prime} & =2 / 3 \times F^{\prime} v \times b \times d \\
V^{\prime} & =2 / 3 \times 4,9 \times 80 \times 120 \\
& =31360 \mathrm{~N}
\end{aligned}
$$

Gaya geser terfaktor $(\mathrm{Vu})$ berdasarkan persamaan (2.28)

$\mathrm{Vu}<\lambda \times \phi v \times \mathrm{V}^{\prime}$

$2590<0,6 \times 0,75 \times 31360$

$2590<14112 \mathrm{~N}$

Berdasarkan hasil perhitungan yang dilakukan diatas bahwa balok dengan ukuran $8 / 12 \mathrm{~cm}$ dengan klasifikasi kuat kayu kelas II aman terhadap gaya geser.

3). Menghitung lendutan balok

Berdasarkan SNI $03-x x x-2000$ lendutan yang diizinkan untuk balok - balok pada struktur bangunan yang terlindung adalah : Lendutan $\mathrm{ijin}=1 / 300 \times \mathrm{L}$ berdasarkan persamaan (2.31) $=1 / 300 \times 3000=10 \mathrm{~mm}$

Kontrol Lendutan berdasarkan persamaan (2.32)

$\mathrm{E}^{\prime}=\mathrm{Ew} \times \mathrm{CM} \times \mathrm{Ct} \times \mathrm{Cpt}$

$=13000 \times 1 \times 1 \times 1$

$=13000 \mathrm{Mpa}$

$\mathrm{I}=\frac{\mathrm{bd}^{3}}{12}=80 \times 120^{3}=73728 \times 10^{6}$

$=\underline{5 \times W L^{4}}=\underline{5 \times 6906 \times 3000^{4}}$ $384 \times \mathrm{EI} 384 \times 13000 \times 73728 \times$ $10^{6}$

$=7,60 \mathrm{~mm}<10 \mathrm{~mm}$

Dari perhitungan diatas dengan melihat hasil lendutan,tegangan lentur dan tegangan geser bahwa dimensi kayu 8/12 dengan klasifikasi kuat kayu kelas II dapat digunakan sebagai balok pada kontruksi rumah panggung.

Menghitung beban kolom

Kolom merupaka kontruksi utama yang menopang seluruh beban dari atap, dinding, lantai dan balok. 


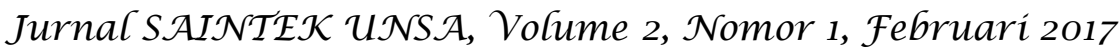

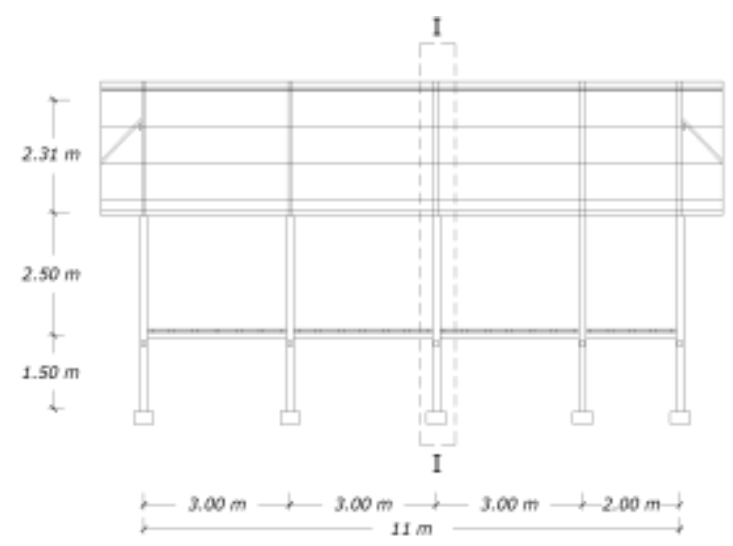

Gambar 24. Potongan kolom yang di tinjau

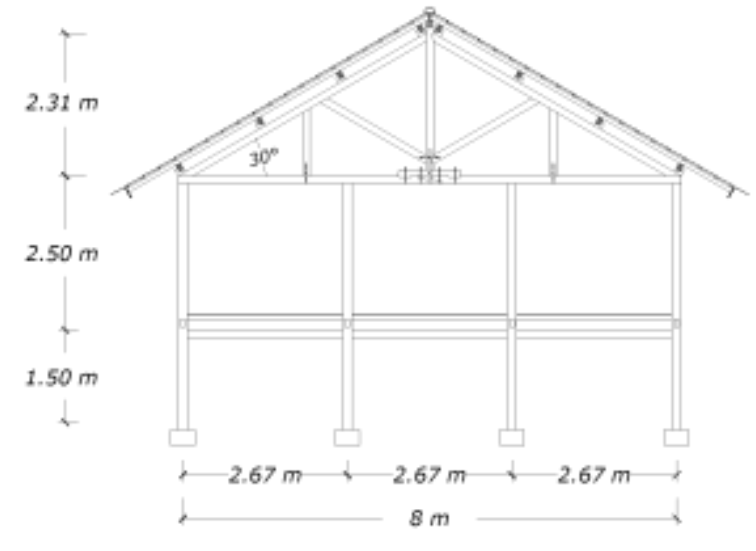

Gambar 25. Potongan I- I

1. Merencanakan kolom struktur Mutu kayu $=$ E14 (SNI $03-x x x-$ 2000)

Dicoba menggunakan ukuran kayu 100/100 mm dengan klasifikasi kuat kayu kelas II.

$\mathrm{b}=100 \mathrm{~mm}$

$\mathrm{h}=100 \mathrm{~mm}$

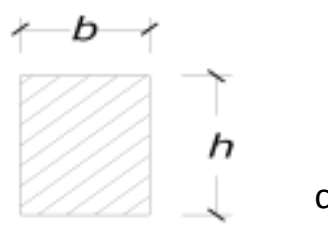

Reaksi tumpuan terbesar $(\mathrm{RA}=\mathrm{RB})$

$=10759,42 \mathrm{~N}$

Berat sendiri kuda - kuda $=0,06 \mathrm{x}$

$0,12 \times 7000 \times 13,24=667 \mathrm{~N}$

Beban total dinding + lantai $=6906 \mathrm{~N}$

Berat sendiri balok $=0,08 \times 0,12 \times$ $7000 \times 3+2,67=381 \mathrm{~N}$

Berat sendiri kolom $=0,10 \times 0,10 \times$ $7000 \times 4=280 \mathrm{~N}+$ q total $=18994 \mathrm{~N}$

2. Menghitung jari - jari girasi $(r)$

$>$ Jari - jari girasi searah sumbu $x$

$$
\begin{aligned}
& r_{\text {min }}=\sqrt{\frac{I m i n}{A}} \\
& r_{x}=\sqrt{\begin{array}{llll}
1 & 100 \times 100
\end{array}}=28,87 \mathrm{~mm}^{4} \\
& 12100100
\end{aligned}
$$

$>$ Jari - jari girasi searah sumbu y

$$
\begin{aligned}
& r_{\text {min }}=\sqrt{\frac{I \min }{A}} \\
& r_{y}=\sqrt{\begin{array}{lll}
1 & 100 \times 100^{3}
\end{array}}=28,87 \mathrm{~mm}^{4}
\end{aligned}
$$

$r x \leq r y=$ maka, $r_{\min }=37,528 \mathrm{~mm}^{4}$, Maka $\mathrm{Ke}=1.00$ sendi - sendi (SNI $03-\mathrm{xxx}-$ 2000)

Angka kelangsingan $(\mathrm{KeL}) / \mathrm{r}=(1 \mathrm{x}$ $4000) / 28,87=138,56<175$ (SNI $03-x x x$ $-2000)$

kuat tekan sejajar serat $(\mathrm{Fc})=30 \mathrm{Mpa}$

$\mathrm{Ew}=13000 \mathrm{Mpa}$

Faktor reduksi $(\varphi)=0.9$

$\mathrm{Ct}=1.00$

$\mathrm{Cf}=1.00$

$\mathrm{Cpt}=1.00$

$\mathrm{Fb}=1.00$

$\mathrm{Cm}=\mathrm{Fb} / \mathrm{Cf}=1 / 1=1.00<8 \mathrm{Mpa}$, maka $\mathrm{Cm}=1.00$

Faktor tahanan stabilitas $(\varphi s)=0.85$

Faktor tahanan tekan $\quad(\varphi c)=0.90$

Faktor waktu $(\lambda)=0.80$

$=0.80$

Kuat tekan sejajar serat $(\mathrm{Fc})$

$\mathrm{Fc}=30 \times 0.9=27 \mathrm{Mpa}$

$\mathrm{Ew}=13000 \mathrm{Mpa}$

3. Menghitung faktor beban berdasarkan persamaan (2.14)

$\mathrm{Fc}^{\prime}=\mathrm{Fc} \times \mathrm{Cm} \times \mathrm{Ct} \times \mathrm{Cpt} \times \mathrm{Cf}$

$$
\begin{aligned}
& =27 \times 1 \times 1 \times 1 \times 1 \\
& =27 \mathrm{Mpa} \\
\mathrm{PC}^{\prime} & =\mathrm{A} \text { bruto } \times \mathrm{Fc}^{\prime} \\
& =100 \times 100 \times 27 \\
& =270000 \mathrm{Mpa}
\end{aligned}
$$




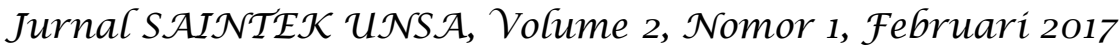

$$
\begin{aligned}
E_{05} & =0,69 \times \mathrm{Ew} \text { (persamaan 2.26) } \\
& =0,69 \times 13000 \\
& =8970 \mathrm{Mpa} \\
\mathrm{Pe} & =\frac{\mathrm{p}^{2} \times \mathrm{E}_{05} \times \mathrm{A}}{\frac{\mathrm{Ke} \times \mathrm{L}}{\mathrm{r}}} \\
r & =0.289 \times \mathrm{b} \\
& =0.289 \times 100 \\
& =28,900 \\
\mathrm{Pe} & =\frac{3.14{ }^{2} \times 8970 \times 16900}{1 \times 4000}
\end{aligned}
$$$$
=16003,670 \mathrm{~N}
$$$$
a c=\frac{0,85 \times 16,003,670}{0.8 \times 0.9 \times 270000}=0,070
$$$$
C p=\frac{1+a c}{2 c} \cdot \sqrt{\frac{1+a c^{2}}{2 c}} \cdot \frac{a c}{c}
$$

$$
\begin{aligned}
C p & =\frac{1+0,070}{1,6} \cdot \sqrt{\frac{1+0,070^{2}}{1,6} \cdot \frac{0,070}{0,8}} \\
& =0,026
\end{aligned}
$$

4. Menghitung tahanan tekan terkoreksi (persamaan 2.35)

$\mathrm{P}^{\prime}=\mathrm{Cp} \times \mathrm{Pc}$

$=0,026 \times 270000$

$=7034,545 \mathrm{~N}$

5. Kontrol tekanan tekan berfaktor

\begin{tabular}{|c|c|c|c|}
\hline Dimensi & $\mathrm{Pu}(\mathrm{N})$ & $<$ & $\begin{array}{c}\text { ? } \mathrm{x} \text { ? } \mathrm{x} \mathrm{P}^{\prime} \\
(\mathrm{N})\end{array}$ \\
\hline $10 / 10$ & 18993.58 & $<$ & 5064.872 \\
\hline $11 / 11$ & 19052.38 & $<$ & 6709.226 \\
\hline $12 / 12$ & 19116.78 & $<$ & 8668.941 \\
\hline $13 / 13$ & 19186.78 & $<$ & 10969.386 \\
\hline $14 / 14$ & 19186.78 & $<$ & 13635.420 \\
\hline $15 / 15$ & 19343.58 & $<$ & 16691.394 \\
\hline $16 / 16$ & 19430.38 & $<$ & 20161.160 \\
\hline $17 / 17$ & 19522.78 & $<$ & 24068.082 \\
\hline $18 / 18$ & 19620.78 & $<$ & 28435.043 \\
\hline $19 / 19$ & 19724.38 & $<$ & 33284.452 \\
\hline $20 / 20$ & 19833.58 & $<$ & 38638.253 \\
\hline
\end{tabular}
berdasarkan persamaan (2.32)

$\mathrm{Pu}<\lambda \times \varphi c \times \mathrm{P}^{\prime}$ $18994<0,80 \times 0,90 \times 7034,545$ $18994<5064,872 \mathrm{~N}$ Tidak aman Dicoba dengan dimensi yang lebih besar dan hasilnya dapat dilihat pada tabel 7.
Tabel 7. Rekapitulasi dimensi kolom dari hasil perhitungan kontruksi

Dari hasil perhitungan beban yang bekerja pada kolom dapat di lihat pada tabel 7 bahwa dimensi 16/16 dapat digunakan sebagai kolom dengan klasifikasi kuat kayu kelas II pada kontruksi rumah panggung.

\section{KESIMPULAN}

Berdasarkan analisis dan pembahasan yang sudah dilakukan pada bab sebelumnya, maka dapat disimpulkan sebagai berikut :

1). Dari hasil perhitungan konstruksi atap dengan mempertimbangkan faktor beban yang bekerja baik beban hidup, beban mati dan beban angin dapat dihasilkan dimensi kayu dengan ukuran $6 / 12 \mathrm{~cm}$ dengan kuat kayu kelas II untuk kontsrusi atap kuda - kuda dengan lendutan maksimum < lendutan ijin yaiut $14,5 \mathrm{~mm}<15 \mathrm{~mm}$.

2). Perencanaan rumah panggung diperhitungkan penggunaan kayu yang sesuai dengan kebutuhan beban yang bekerja yang terlihat pada dimensi balok dan kolom dari hasil perhitungan beban yang terjadi pada kontruksi atap dan lantai didapat dimensi balok 8/12 $\mathrm{cm}$ dengan klasifikasi kuat kayu kelas II dengan faktor lendutan maksimum $8,69 \mathrm{~mm}$ dan lendutan ijin $10 \mathrm{~mm}$.

3). Dari hasil perhitungan seluruh beban yang bekerja dapat dihasilkan dimensi kolom dengan ukuran 16/16 cm dengan klasifikasi kuat kayu kelas II. 
SARAN

Dari kesimpulan - kesimpulan diatas penulis memberikan saran yang kiranya dapat berguna dalam hal perencanaan rumah panggung khususnya pada pulau Sumbawa.

1). Berdasarkan hasil penelitian yang sudah dilakukan, diharapkan kepada pemerintah untuk mensosialisasikan pembangunan konstruksi khsusnya konstruksi rumah panggung kayu kepada masyarakat pulau Sumbawa dengan tujuan masyarakat mengerti tentang tata cara perencanaan rumah panggung yang aman dan benar.

2). Dengan adanya penelitian ini, diharapkan kepada masyarakat pulau Sumbawa untuk dapat meminimalisir penggunaan kayu sehingga alam dapat terjaga serta masyarakat luas tidak meninggalkan ciri khas bangunan rumah panggung demi memelihara adat atau tradisi yang sudah ada.

3). Untuk penelitian berikutnya dapat mengembangkan desain rumah panggung yang lebih modern sehingga masyarakat tetap berminat membangun rumah panggung sebagai cirri khas rumah adat pulau Sumbawa.

\section{DAFTAR PUSTAKA}

Anonim (1961), "Peraturan Konstruksi Kayu Indonesia (PKKI) NI 5-1961" Departemen pekerjaan umum : Bandung

Anonim (2000), "Tata Cara Perencanaan Struktur Kayu Untuk Bangunan Gedung (SK SNI $03-x x x-2000$ )" :Bandung

Anonim (2013), "Spesifikasi Desain Untuk Konstruksi Kayu (SNI 7973-2013)". Badan standarisasi nasional : Jakarta

Anonim (1983), Peraturan Pembebanan Idonesia Untuk Bangunan Gedung, Yayasan Lembaga Penyelidikan Masalah Bangunan: Bandung

Awaludin,A. (2002). Konstruksi Kayu. Biro Penerbit KMTS Jurusan Teknik Sipil FT UGM, Yogyakarta
Felix Yap, K.H. (1994). Konstruksi Kayu, PT. Gramedia Pustaka Utama : Jakarta

Felix Yap, K.H. (1965). Konstruksi Kayu, Bina Cipta, : Bandung

Frick Heinz,ir. (1999). Ilmu Konstruksi Bangunan Kayu, Kanisius : Yogyakarta

Ghali. A (1999). Analisa Struktur, Erlangga : Jakarta

Hariandja Binsar (1996). Mekanika Teknik, Erlangga : Jakarta

Jopie F. Dumanauw (1990). Mengenal Kayu, Karnisius: Yogyakarta

King Wang (1991). Statis Tak Tentu, Erlangga : Jakarta

L. Schodek. Danil (1998). Struktur, Refika Aditama : Bandung

L. Schodek. Danil (1999). Struktur (Edisi Kedua), Erlangga : Jakarta

Mulyati (2016). Bahan Ajar Struktur Kayu.(Online) (http://BahanAjar/Mulyati/Struktur Kayu/Materi/Pertemuan 20XII,XIII,XIV,XV).

Purnama, A, 2011. Studi Kelayakan Pembangunan Pembangkit Listrik Tenaga Mikrohidro Studi Kasus: PLTMH Minggir pada saluran irigasi Minggir di Padukuhan Klagaran Desa Sendangrejo Kecamatan Minggir Kabupaten Sleman, Jurnal Unsa Progress. Vol.10, No.15, Oktober, Universitas Samawa, Sumbawa Besar.

Steiger Ludwig (2010). Kontruksi Kayu, Erlangga : Jakarta

Sugeng (2015). Batangtekan (Online) (http://sugengpb.lecture.ub.ac.id/f iles/2015/03/Batang-Tekan.)

V Sungguno . ir K.H (1984) Buku Teknik Sipil, Nova : Bandung

Wesli. (2010). Mekanika Rekayasa . Graha Ilmu : Yogyakarta

Wiryomartono Suarno (1998). Kontruksi Kayu Jilid 1. FT UGM, Yogyakarta 